\title{
Vapochromism in Complexes of Stoichiometry $\left[\mathrm{Au}_{2} \mathrm{Ag}_{2} \mathbf{R}_{4} \mathbf{L}_{2}\right]_{n}$
}

\author{
Eduardo J. Fernández ${ }^{\mathrm{a}}$, Antonio Laguna ${ }^{\mathrm{b}}$, José M. López-de-Luzuriaga ${ }^{\mathrm{a}}$, M. Elena Olmos ${ }^{\mathrm{a}}$ \\ and Raquel C. Puelles ${ }^{a}$ \\ ${ }^{a}$ Departamento de Química, Universidad de la Rioja, Grupo de Síntesis Química de La Rioja, \\ UA-CSIC, Complejo Científico Tecnológico, 26001 Logroño, Spain \\ b Departamento de Química Inorgánica, Instituto de Ciencia de Materiales de Aragón, \\ Universidad de Zaragoza-CSIC, 50009 Zaragoza, Spain
}

Reprint requests to J. M. López-de-Luzuriaga. E-mail: josemaria.lopez@unirioja.es

Z. Naturforsch. 2009, 64b, 1500 - 1512; received September 24, 2009

Dedicated to Professor Hubert Schmidbaur on the occasion of his $75^{\text {th }}$ birthday

Reaction of $\left[\mathrm{NBu}_{4}\right]\left[\mathrm{Au}\left(\mathrm{C}_{6} \mathrm{X}_{5}\right)_{2}\right] \quad\left(\mathrm{C}_{6} \mathrm{X}_{5}=3,5-\mathrm{C}_{6} \mathrm{Cl}_{2} \mathrm{~F}_{3}, \mathrm{C}_{6} \mathrm{Cl}_{5}\right)$ with $\mathrm{AgOClO}_{3}$ in an $\mathrm{Et}_{2} \mathrm{O} / \mathrm{CH}_{2} \mathrm{Cl}_{2}$ mixture affords $\left[\mathrm{Au}_{2} \mathrm{Ag}_{2}\left(\mathrm{C}_{6} \mathrm{X}_{5}\right)_{4}\left(\mathrm{OEt}_{2}\right)_{2}\right]_{n}\left[\mathrm{C}_{6} \mathrm{X}_{5}=3,5-\mathrm{C}_{6} \mathrm{Cl}_{2} \mathrm{~F}_{3}(\mathbf{1 a}), \mathrm{C}_{6} \mathrm{Cl}_{5}(\mathbf{1 b})\right]$ These compounds react with tetrahydrofuran, acetone, acetonitrile or toluene in solution and in the gas phase (with toluene only in solution) to the new complexes $\left[\mathrm{Au}_{2} \mathrm{Ag}_{2}\left(\mathrm{C}_{6} \mathrm{X}_{5}\right)_{4} \mathrm{~L}_{2}\right]_{n}[\mathrm{~L}=\mathrm{THF}(\mathbf{2 a}$, 2b), $\left.\left(\mathrm{CH}_{3}\right)_{2} \mathrm{CO}(\mathbf{3 a}, \mathbf{3 b}), \mathrm{CH}_{3} \mathrm{CN}(\mathbf{4 a}, 4 \mathbf{b}), \mathrm{C}_{7} \mathrm{H}_{8}(\mathbf{5 a}, \mathbf{5 b})\right]$. The crystal structures of $\mathbf{2 a}$ and $\mathbf{5 a}$ have been determined by $\mathrm{X}$-ray diffraction methods, showing polymeric chains formed by the union of tetranuclear $\mathrm{Au}_{2} \mathrm{Ag}_{2}$ units via aurophilic interactions. The thermal stability and the vapochromic behaviour of these complexes have been studied by thermogravimetric analysis (TGA), X-ray powder diffraction and FT-IR spectroscopy.

Key words: Gold, Silver, Luminescence, Vapochromism

\section{Introduction}

A plethora of examples of crystal structures displaying short distances between gold(I) atoms in the solid state led Schmidbaur to coin the term aurophilicity [1]. Various examples of structural evidence for this induced some scientists to carry out theoretical studies that allowed the scientific community to accept this phenomenon in gold compounds as a standard characteristic of this element in its complexes. Aurophilicity even became a model for the description of relativistic effects in closed-shell metals, of which gold(I) is the best example [2]. This phenomenon has afterwards been extended and studied in other complexes showing metal-metal distances shorter than the sum of their van-der-Waals radii. Thus, such interactions have been found between gold(I) and other closedshell metal atoms $(\mathrm{Au} \cdots \mathrm{M})$ or even between metals different from gold with $d^{10}-d^{10}, s^{2}-d^{8}$ or $d^{8}-d^{10}$ configurations [3-19]. In some cases theoretical studies of selected examples have been carried out [2], concluding that these interactions always have non-negligible contributions arising from dispersion forces reinforced by relativistic effects, which reach a maximum for the gold compounds [20]. In addition, these heterometallic complexes are interesting not only from a theoretical point of view, but also because of the photophysical properties observed in many of them [21] and their potential applications [22-34]. Therefore, the search of complexes with $\mathrm{Au}(\mathrm{I})-\mathrm{M}$ (closed-shell metal ion) is one of the most active research topics in many laboratories working with this metal.

The number of gold-silver, or even more, goldcopper complexes is nowadays still scarce when compared to the number of compounds with homometallic interactions, although one should expect that the other members of the coinage metal group would be the best candidates to form heterometallic complexes with gold. In the particular case of gold-silver complexes, a number of species displaying $\mathrm{Au}(\mathrm{I}) \cdots \operatorname{Ag}(\mathrm{I})$ interactions has recently been described. The most common strategy for their synthesis is the use of asymmetric polydentate ligands that can act as a bridge between the metal centres $[20,35,36]$, and, in particular, the reaction of $\left[\mathrm{Au}\left(\mathrm{L}-\mathrm{L}^{\prime}\right)_{2}\right]^{+}$with equimolecular amounts of a silver(I) salt, such as $\operatorname{AgTfO}\left(\mathrm{TfO}=\mathrm{CF}_{3} \mathrm{SO}_{3}\right)[20,35 \mathrm{~b}], \mathrm{Ag}\left(\mathrm{OClO}_{3}\right)$ [36a], or $\mathrm{AgBF}_{4}[35 \mathrm{~d}]$. A different synthetic strategy 
is the reaction between a donor metallic system, such as $\left[\mathrm{Au}\left(\mathrm{C}_{6} \mathrm{~F}_{5}\right)_{2}\right]^{-}$[37], $\left[\mathrm{Au}\left(\mathrm{CH}_{2} \mathrm{PR}_{3}\right)_{2}\right]^{+}$[38], $\left[\mathrm{Au}_{2}\left(\mathrm{CH}_{2} \mathrm{SiMe}_{3}\right)_{2}\left(\mu\right.\right.$-dppm)] [39] or $\left[\mathrm{Au}\left(\mu-\mathrm{C}^{2}, \mathrm{~N}^{3}-\right.\right.$ bzim) $]_{3}[40]$ (bzim $=1$-benzylimidazolate), and the same acid $\mathrm{Ag}^{+}$salts as above. In particular, the use of perhalophenylgold(I) derivatives is a well-established and effective method to prepare heterometallic materials in our group. Thus, by using $\left[\mathrm{Au}\left(\mathrm{C}_{6} \mathrm{X}_{5}\right)_{2}\right]^{-}$or $\left[\mathrm{Au}\left(\mathrm{C}_{6} \mathrm{X}_{5}\right)(\mathrm{tht})\right](\mathrm{X}=\mathrm{Cl}, \mathrm{F})$ we were successful in achieving the formation of $\mathrm{Au} \cdots \mathrm{Ag}$ interactions, taking advantage of, firstly, the donor characteristics of the gold precursor, secondly, the bridging capabilities of these groups and, thirdly, the stability that these ligands confer to the complexes. For instance, complexes as the monodimensional polymers $\left[\mathrm{Au}_{2} \mathrm{Ag}_{2}\left(\mathrm{C}_{6} \mathrm{~F}_{5}\right)_{4} \mathrm{~L}_{2}\right]_{n}$ ( $\mathrm{L}=$ neutral ligand $)$, the polymeric nature of which results from additional gold-gold contacts between tetranuclear units, are obtained. These interactions are also considered responsible for the optical properties of these complexes. Recently we described another interesting property of these complexes, which is their vapochromic behaviour [41], concluding that the reaction between $\left[\mathrm{Au}_{2} \mathrm{Ag}_{2}\left(\mathrm{C}_{6} \mathrm{~F}_{5}\right)_{4} \mathrm{~L}_{2}\right]_{n}(\mathrm{~L}=\mathrm{THF}$, $\left.\left(\mathrm{CH}_{3}\right)_{2} \mathrm{CO}, \mathrm{CH}_{3} \mathrm{CN}, \mathrm{C}_{7} \mathrm{H}_{8}\right)$ and volatile organic compounds (VOCs) are substitution reactions rather than superficial adsorption processes, and that the exchange ability of the VOCs follows an order close to their boiling points.

In order to continue analysing the influence of other factors on this behaviour, as the donor characteristics of the bis(aryl)aurate groups, we have synthesised the related complexes $\left[\mathrm{Au}_{2} \mathrm{Ag}_{2}\left(\mathrm{C}_{6} \mathrm{Cl}_{2} \mathrm{~F}_{3}\right)_{4} \mathrm{~L}_{2}\right]_{n}$ and $\left[\mathrm{Au}_{2} \mathrm{Ag}_{2}\left(\mathrm{C}_{6} \mathrm{Cl}_{5}\right)_{4} \mathrm{~L}_{2}\right]_{n}\left(\mathrm{~L}=\mathrm{THF},\left(\mathrm{CH}_{3}\right)_{2} \mathrm{CO}, \mathrm{CH}_{3} \mathrm{CN}\right.$, $\left.\mathrm{C}_{7} \mathrm{H}_{8}\right)$ and studied their reactions with VOCs.

\section{Results and Discussion}

\section{Synthesis and characterisation}

Reaction of $\left[\mathrm{NBu}_{4}\right]\left[\mathrm{Au}\left(\mathrm{C}_{6} \mathrm{X}_{5}\right)_{2}\right]\left(\mathrm{C}_{6} \mathrm{X}_{5}=3,5\right.$ $\mathrm{C}_{6} \mathrm{Cl}_{2} \mathrm{~F}_{3}, \mathrm{C}_{6} \mathrm{Cl}_{5}$ ) with equimolecular amounts of silver perchlorate in a mixture of diethyl ether and dichloromethane leads to the complexes $\left[\mathrm{Au}_{2} \mathrm{Ag}_{2}\left(\mathrm{C}_{6} \mathrm{X}_{5}\right)_{4}\left(\mathrm{OEt}_{2}\right)_{2}\right]_{n} \quad\left[\mathrm{C}_{6} \mathrm{X}_{5}=3,5-\mathrm{C}_{6} \mathrm{Cl}_{2} \mathrm{~F}_{3}\right.$ (1a), $\mathrm{C}_{6} \mathrm{Cl}_{5}$ (1) $]$ in high yields. Analytical and spectroscopic data of these complexes agree with the proposed stoichiometry (see the Experimental Section). Thus, their IR spectra show, among others, absorptions at 1588, 1557, 1057 and $783 \mathrm{~cm}^{-1}$ (1a) or 839 and $622 \mathrm{~cm}^{-1}(\mathbf{1 b})$, arising from the presence of trifluorodichlorophenyl or pentachlorophenyl groups bonded to gold(I). Their mass spectra (MALDI-TOF) show signals corresponding to $\left[\mathrm{Au}_{2} \mathrm{Ag}\left(\mathrm{C}_{6} \mathrm{Cl}_{2} \mathrm{~F}_{3}\right)_{4}\right]^{-}$ at $m / z=1302(10 \%)$ and $\left[\mathrm{Au}_{2}\left(\mathrm{C}_{6} \mathrm{Cl}_{5}\right)_{3}\right]^{-}$at $\mathrm{m} / \mathrm{z}=$ $1142(25 \%)$, with the expected isotopic distribution. Besides, the ${ }^{19} \mathrm{~F}$ NMR spectrum of complex 1a shows the pattern corresponding to two types of non equivalent fluorine atoms at -88.1 and $-117.6 \mathrm{ppm}$, respectively, that appear as singlets.

These compounds are soluble in most conventional solvents (tetrahydrofuran, acetone, acetonitrile, etc.), and non-soluble in $n$-hexane or diethyl ether. Evaporation of the solvent from these solutions does not regenerate the initial starting products, but new species in which the solvent substitutes the ether molecules initially bonded to silver are recovered instead. Therefore, dissolution of complexes $\mathbf{1 a}$ or $\mathbf{1 b}$ in tetrahydrofuran, acetone, acetonitrile or toluene, evaporation of the solvent to dryness and addition of hexane allowed the synthesis of the related compounds $\left[\mathrm{Au}_{2} \mathrm{Ag}_{2}\left(\mathrm{C}_{6} \mathrm{Cl}_{2} \mathrm{~F}_{3}\right)_{4} \mathrm{~L}_{2}\right]_{n}$ (a) and $\left[\mathrm{Au}_{2} \mathrm{Ag}_{2}\left(\mathrm{C}_{6} \mathrm{Cl}_{5}\right)_{4} \mathrm{~L}_{2}\right]_{n}$ (b) $[\mathrm{L}=\operatorname{THF}(\mathbf{2 a}, \mathbf{2 b})$, $\left.\left(\mathrm{CH}_{3}\right)_{2} \mathrm{CO}(\mathbf{3 a}, \mathbf{3 b}), \mathrm{CH}_{3} \mathrm{CN}(\mathbf{4 a}, \mathbf{4 b}), \mathrm{C}_{7} \mathrm{H}_{8}(\mathbf{5 a}, \mathbf{5 b})\right]$.

Similarly to the precursor complexes $\mathbf{1 a}$ and $\mathbf{1 b}$, all spectroscopic and analytical data of $\mathbf{2 - 5}$ are in accordance with the proposed stoichiometries. In the case of complexes a, the absorptions due to the 3,5dichlorotriflurophenyl groups in their IR spectra appear at similar frequencies as the ones in the precursor complex 1a. The bands due to the neutral ligands in the spectra of both complexes $\mathbf{a}$ and $\mathbf{b}$ also appear at 917 (2a) or 922 (2b), 1687 (3a), 2305$2275(\mathbf{4 a})$ or $2304-2270 \mathrm{~cm}^{-1}$ (4b) for the ether, ketone, and nitrile groups, respectively, or at $760-$ $693(\mathbf{5 a})$ or $765-702 \mathrm{~cm}^{-1}(\mathbf{5 b})$, indicating the presence of the toluene molecules. All these neutral ligands are detected in the ${ }^{1} \mathrm{H}$ NMR spectra, which show the expected resonances. In all cases the mass spectra (MALDI-TOF), using dithranol as matrix, show fragments corresponding to the dissociation of the tetranuclear units, with the peak corresponding to the unit $\left[\mathrm{Au}_{2} \mathrm{Ag}\left(\mathrm{C}_{6} \mathrm{Cl}_{2} \mathrm{~F}_{3}\right)_{4}\right]^{-}(\mathrm{m} / \mathrm{z}=1301)$ as the peak of highest molecular weight for all the dichlorotrifluorophenyl derivatives a. The homologous peak for the pentachlorophenyl complexes $\mathbf{b}\left(\left[\mathrm{Au}_{2} \mathrm{Ag}\left(\mathrm{C}_{6} \mathrm{Cl}_{5}\right)_{4}\right]^{-}\right.$at $m / z=1449$ ) appears in complexes $\mathbf{2 b}$ and $\mathbf{5} \mathbf{b}$, while the parent peak is the one corresponding to the fragment $\left[\mathrm{Au}\left(\mathrm{C}_{6} \mathrm{Cl}_{5}\right)_{2}\right]^{-}(\mathrm{m} / \mathrm{z}=695)$.

In general all the complexes show a limited solubility in acetone or acetonitrile, which prevents the determination of their molar conductivity in solution. In 

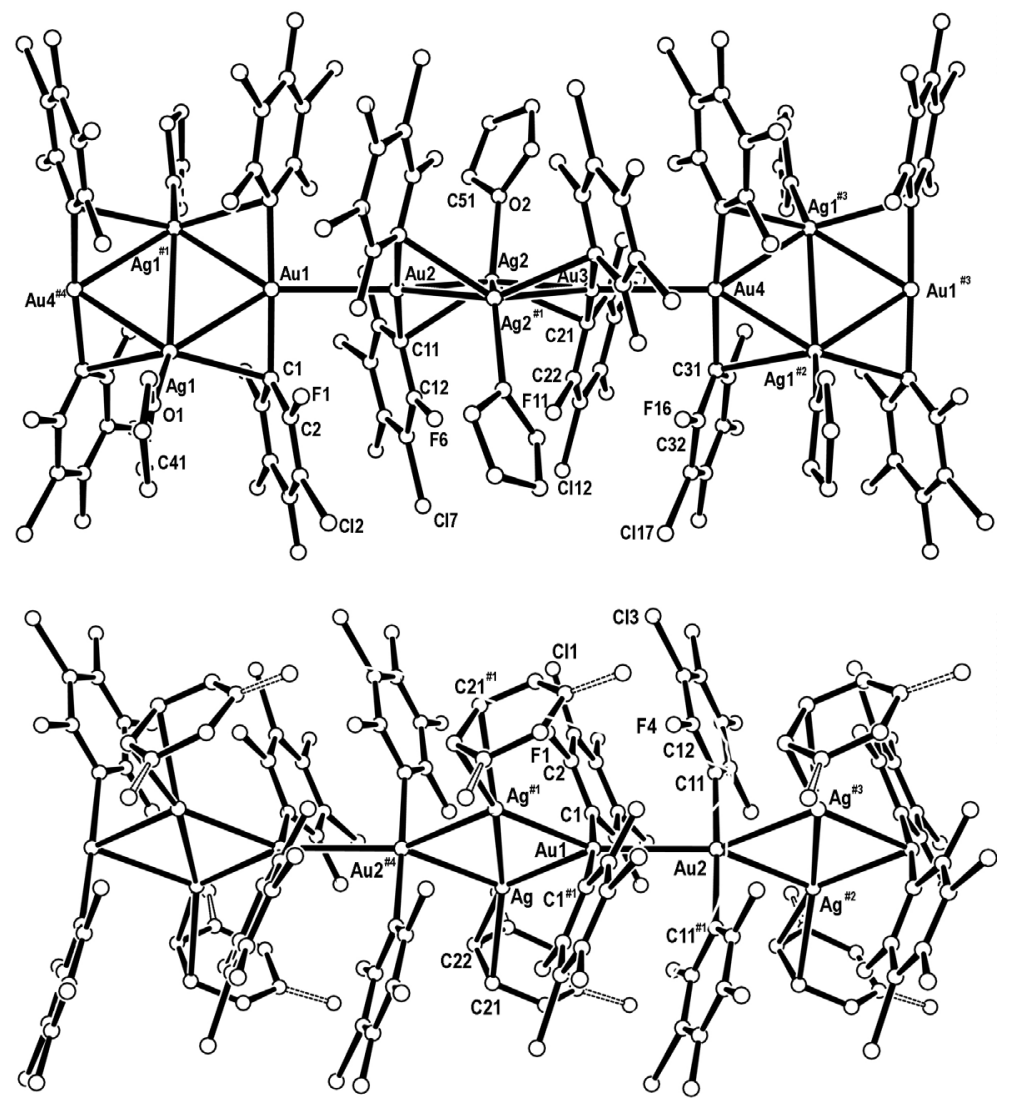

Fig. 1. Polymeric structure of complex $\mathbf{2 a}$ (hydrogen atoms omitted for clarity).
Fig. 2. Polymeric structure of complex $\mathbf{5 a}$ (hydrogen atoms omitted for clarity). addition, as will be commented below, all the neutral ligands can be at least partially substituted by acetonitrile, and therefore, the only molar conductivity measurement that could be properly determined was that of complex $\mathbf{4 a}$ in acetonitrile, which, as expected, shows a typical value of $1: 1$ electrolytes.

Crystal structures of $\left[\mathrm{Au}_{2} \mathrm{Ag}_{2}\left(\mathrm{C}_{6} \mathrm{Cl}_{2} \mathrm{~F}_{3}\right)_{4}(\mathrm{THF})_{2}\right]_{n}$ (2a) and $\left\{\left[\mathrm{Au}_{2} \mathrm{Ag}_{2}\left(\mathrm{C}_{6} \mathrm{Cl}_{2} \mathrm{~F}_{3}\right)_{4}\left(\eta^{2}-\mathrm{C}_{7} \mathrm{H}_{8}\right)_{2}\right] \cdot \mathrm{C}_{7} \mathrm{H}_{8}\right\}_{n}$ (5a)

The crystal structures of complexes $\mathbf{2 a}$ and $\mathbf{5 a}$ were determined from single crystals obtained by slow diffusion of hexane into a solution of the complex in THF (2a) or toluene (5a). As all the structures previously described for related derivatives of formula $\left[\mathrm{Au}_{2} \mathrm{Ag}_{2}\left(\mathrm{C}_{6} \mathrm{~F}_{5}\right)_{4} \mathrm{~L}_{2}\right]_{n}\left(\mathrm{~L}=\mathrm{SC}_{4} \mathrm{H}_{8}\right.$ [37a], $\mathrm{C}_{6} \mathrm{H}_{6}$ [37b], $\mathrm{Me}_{2} \mathrm{CO}$ [37c], THF [41] or NCMe [42]), both complexes crystallise in the monoclinic space group $C 2 / c$ and consist of tetranuclear $\left[\mathrm{Au}_{2} \mathrm{Ag}_{2}\left(\mathrm{C}_{6} \mathrm{Cl}_{2} \mathrm{~F}_{3}\right)_{4} \mathrm{~L}_{2}\right]$ units linked together via aurophilic contacts resulting in $1 \mathrm{D}$ polymers that run parallel to the crystal- lographic $y$ axis (Figs. 1 and 2). The intermolecular $\mathrm{Au}-\mathrm{Au}$ distances of 2.8617(7) and 2.8863(7) $\AA$ in 2a and of 2.9092(3) $\AA$ in $\mathbf{5 a}$ are appreciably shorter than those found in the related pentafluorophenyl derivates with THF (3.1959(3) А) [41], benzene

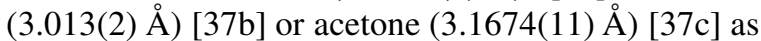
ligands bonded to silver and closer to those described for $\left[\mathrm{Au}_{2} \mathrm{Ag}_{2}\left(\mathrm{C}_{6} \mathrm{~F}_{5}\right)_{4}\left(\mathrm{SC}_{4} \mathrm{H}_{8}\right)_{2}\right]_{n}$ [37a] (2.889(2) $\AA$ ) or $\left[\mathrm{Au}_{2}\left(\mathrm{C}_{6} \mathrm{~F}_{5}\right)_{4} \mathrm{M}_{2}(\mathrm{NCMe})_{2}\right](\mathrm{M}=\operatorname{Ag}(2.8807(4) \AA)$, $\mathrm{Cu}(2.9129(3) \AA)$ ) [42], suggesting a substantial bonding interaction between the gold centres. In addition to the intermolecular $\mathrm{Au} \cdots \mathrm{Au}$ contacts, there are also argentophilic intramolecular interactions within the $\mathrm{Au}_{2} \mathrm{Ag}_{2}$ core, displaying $\mathrm{Ag}-\mathrm{Ag}$ distances of 3.0700(14) and 3.1487(14) $\AA$ (2a) or 3.0401(7) $\AA$ (5a), which are in general shorter than in the related pentafluorophenyl complexes of 3.2291(6) $\AA$ in the THF species [41] or $3.070 \AA$ in the benzene derivative [37b].

The gold(I) atoms are linearly coordinated to two perhalophenyl groups with typical $\mathrm{Au}-\mathrm{C}$ distances 

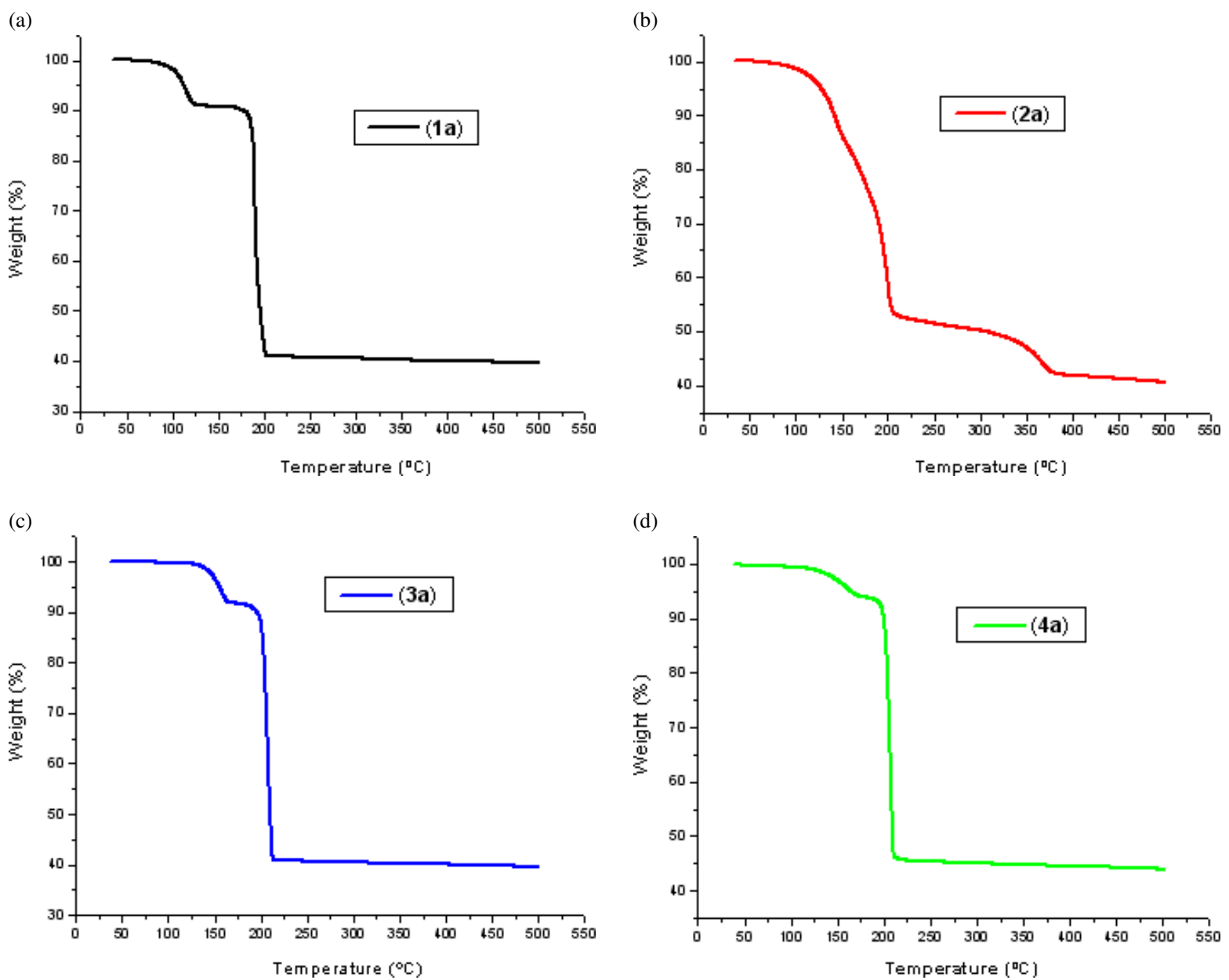

Fig. 3. TGA traces for complexes 1a (left, above) (black), 2a (right, above) (red), 3a (left, below) (blue), and 4a (right, below) (green) (colour online).

(from 2.052(8) to 2.079(8) $\AA$ in $\mathbf{2 a}$ and of 2.055(4) and 2.056(4) $\AA$ in 5a) and display additional $\mathrm{Au}-\mathrm{Ag}$ contacts within the tetranuclear unit between 2.7144(8) and 2.7629(8) $\AA$ in the THF (2a) and of 2.7003(4) and 2.7710 (4) $\AA$ in the toluene derivatives (5a). The former distance in all cases is shorter than those found in the structures of the previously described related complexes $\left[\mathrm{Au}_{2} \mathrm{Ag}_{2}\left(\mathrm{C}_{6} \mathrm{~F}_{5}\right)_{4} \mathrm{~L}_{2}\right]_{n}[37,41,42]$ (between 2.7267(5) and 2.7903(9) $\AA$ ), while the latter lies within this range.

As in the other complexes of the type $\left[\mathrm{Au}_{2}\left(\mathrm{C}_{6} \mathrm{~F}_{5}\right)_{4}\right.$ $\left.\mathrm{Ag}_{2} \mathrm{~L}_{2}\right]_{n}[37,41,42]$ each neutral ligand $\mathrm{L}$ is coordinated to one silver(I) centre. In the case of the THF derivative 2a the Ag-O bond length, of 2.284(8) and 2.286(8) $\AA$ are shorter than in the pentafluorophenyl compounds with $O$-donor ligands, such as tetrahydrofuran (2.307(3) $\AA$ ) [41] or acetone (2.537(7) ^) [37c]. The coordinated toluene molecule in 5a (in which the methyl group is disordered over two positions) acts as $\eta^{2}$ ligand, showing very different Ag-C lengths of 2.422(4) and 2.534(5) $\AA$, while in $\left[\mathrm{Au}_{2} \mathrm{Ag}_{2}\left(\mathrm{C}_{6} \mathrm{~F}_{5}\right)_{4}\left(\eta^{2}-\mathrm{C}_{6} \mathrm{H}_{6}\right)_{2}\right]_{n}$ the coordination of the benzene is more symmetrical (Ag-C: 2.480(10) and 2.498(12) ^) [37b].

The main difference between both structures is that, while in 5a the perhalophenyl groups interact only with gold, in $\mathbf{2 a}$ the aryl groups act as asymmetrical bridges between gold and silver (Fig. 1) with $\mathrm{Au}-\mathrm{C}$ distances from 2.052(8) to 2.079(8) $\AA$ and Ag-C distances from 2.463(7) to 2.593(7) $\AA$, showing a situation similar to those described in some of the related structures [37c, 41, 42]. 


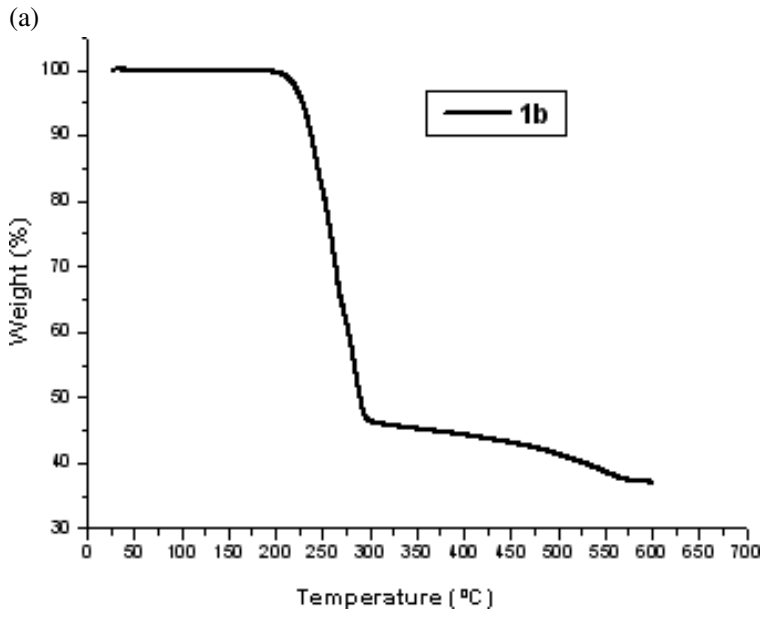

(c)

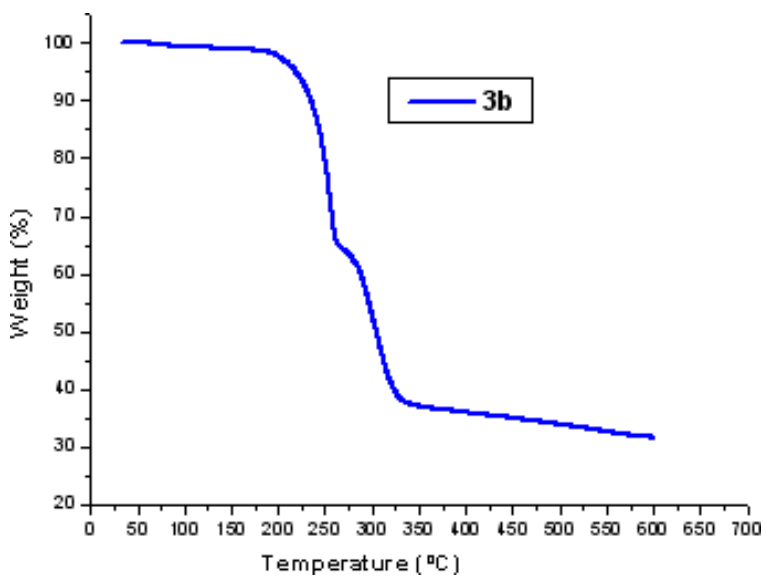

(b)

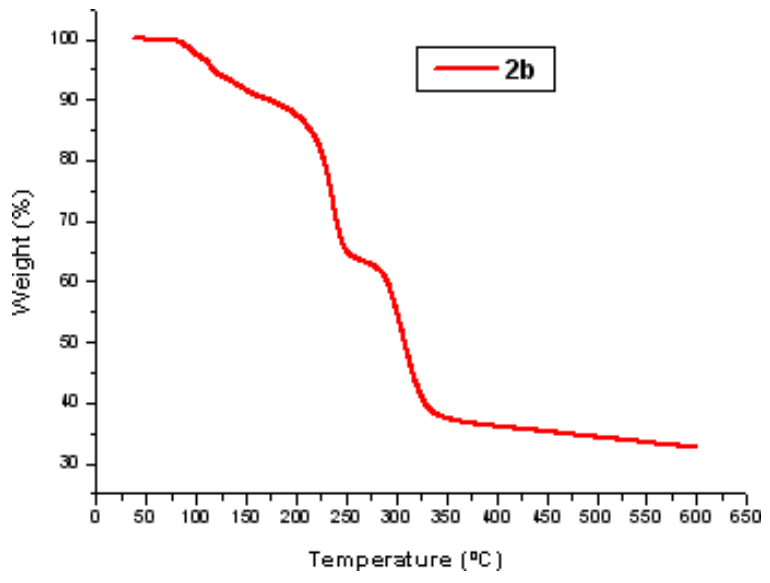

(d)

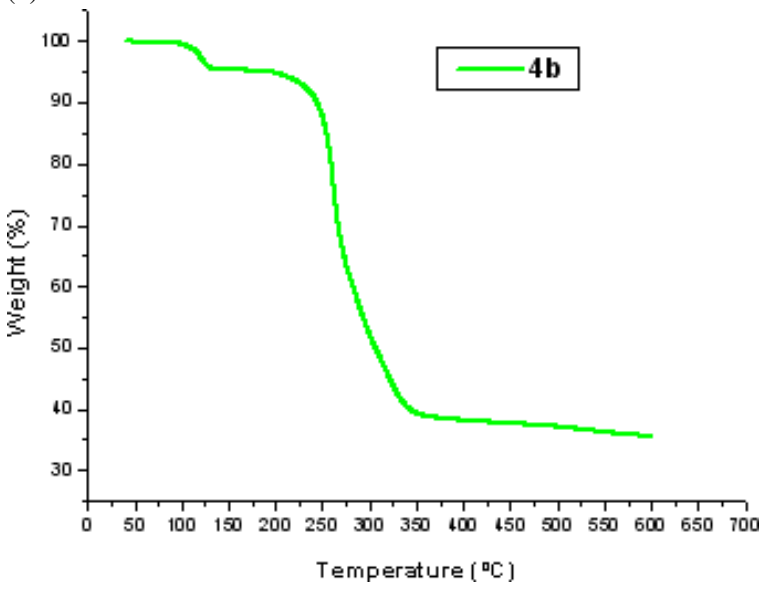

Fig. 4. TGA traces for complexes $\mathbf{1 b}$ (left, above) (black), $\mathbf{2 b}$ (right, above) (red), $\mathbf{3 b}$ (left, below) (blue), and $\mathbf{4 b}$ (right, below) (green) (colour online).

\section{Vapochromic studies}

Very interestingly, all the complexes described show perceptible changes when they are exposed to vapours of the volatile organic compounds employed as ligands for the synthesis of complexes $\mathbf{a}$ and $\mathbf{b}$. Thus, the exposition leads to changes in the colour of the samples. This vapochromic behaviour has been studied by different techniques as, for example, thermogravimetric analyses (TGA), powder diffraction or FT-IR spectroscopy.

\section{Thermogravimetric studies}

Thermogravimetric studies of the samples obtained from the exposure of $\mathbf{1 a}$ or $\mathbf{1 b}$ to different organic vapours show, in general, significant differences be- tween the TGA spectra for the $\mathrm{C}_{6} \mathrm{Cl}_{2} \mathrm{~F}_{3}$ (a) and the $\mathrm{C}_{6} \mathrm{Cl}_{5}$ (b) derivatives and are more simple than those previously reported for the related pentafluorophenyl species [41].

In complexes a, with the exception of the THF derivative, at a temperature of about $215^{\circ} \mathrm{C}$, nearly all of the organic material is lost, leaving an equal amount of silver and gold (Fig. 3), while in the other compounds this loss of organic material occurs at about $325-375{ }^{\circ} \mathrm{C}(\mathbf{2 a}, \mathbf{2 b}, \mathbf{3 b}, \mathbf{4 b})$ or at about $550-575{ }^{\circ} \mathrm{C}$ (1b) (Fig. 4). The TGA traces for complexes 1a, 3a and 4a display similar profiles, showing the loss of both molecules of $\mathrm{Et}_{2} \mathrm{O}, \mathrm{Me}_{2} \mathrm{CO}$ or NCMe between 75 and $135{ }^{\circ} \mathrm{C}(\mathbf{1 a})$ or between 120 and $175{ }^{\circ} \mathrm{C}$ (2a or 4a). From 175 to $215^{\circ} \mathrm{C}$ a drastic weight loss of about a $50 \%$ is observed, corresponding to the loss of the 


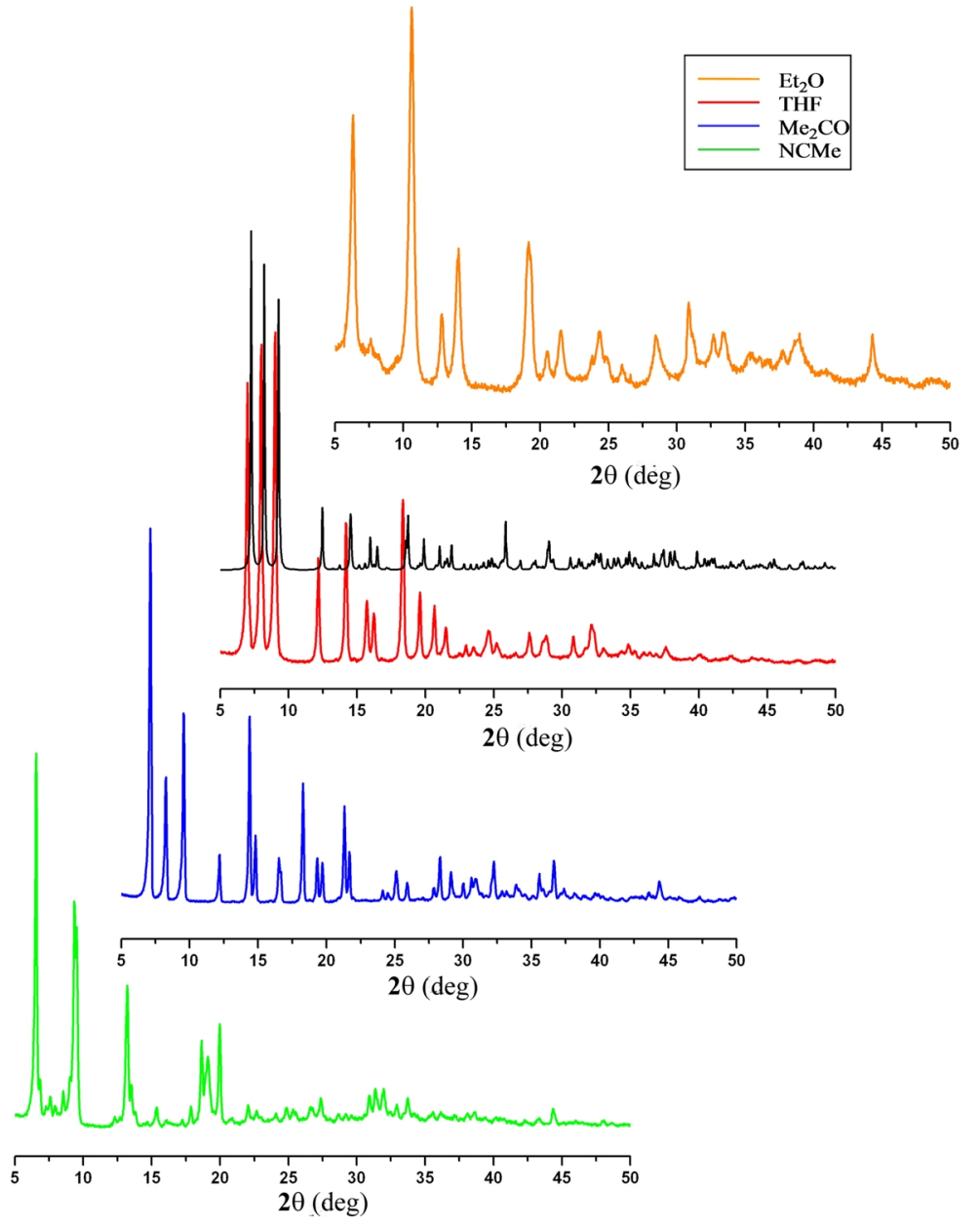

Fig. 5. XPD diffraction patterns for VOC Au-Ag materials obtained by treatment of 1a (orange) with THF (red), acetone (blue) and acetonitrile (green) (colour online). four perhalophenyl substituents as $\mathrm{HC}_{6} \mathrm{~F}_{3} \mathrm{Cl}_{2}$, due a reductive elimination, which has also been detected by gas-mass spectrometry. In the TGA trace of $\mathbf{2 a}$ the first slope (between 75 and $215^{\circ} \mathrm{C}$ ) corresponds to the loss of the THF molecules and three of the four aryl groups in the form of $\mathrm{HC}_{6} \mathrm{Cl}_{2} \mathrm{~F}_{3}$ or $\mathrm{C}_{6} \mathrm{Cl}_{2} \mathrm{~F}_{3}-\mathrm{C}_{6} \mathrm{Cl}_{2} \mathrm{~F}_{3}$ (or both), and the remaining perhaloaryl group is lost between 215 and $375{ }^{\circ} \mathrm{C}$ as $\mathrm{HC}_{6} \mathrm{Cl}_{2} \mathrm{~F}_{3}$.

In the case of complexes $\mathbf{b}$ they all display different behaviour with increasing temperature (Fig. 4), and thus the TGA curve for the diethyl ether complex $\mathbf{1 b}$ is similar to that for the tetrahydrofuran complex $\mathbf{2 a}$, showing the loss of both ether molecules and three pentacholophenyl ligands between 200 and $300{ }^{\circ} \mathrm{C}$, while the fourth $\mathrm{C}_{6} \mathrm{Cl}_{5}$ group is lost at temperatures between 300 and $575{ }^{\circ} \mathrm{C}$. In the case of $\mathbf{2 b}$, the TGA trace is more complex, and the first tetrahydrofuran molecule appears to be lost between 75 and $100{ }^{\circ} \mathrm{C}$, while the second loss occurs from 120 to $180{ }^{\circ} \mathrm{C}$. Two perhalophenyl ligands are lost between 180 and $250{ }^{\circ} \mathrm{C}$, and the other two between 270 and $325^{\circ} \mathrm{C}$. In the acetone derivative $\mathbf{3 b}$, both acetone molecules and two perhalophenyl groups are lost between 175 and $260{ }^{\circ} \mathrm{C}$, and the last two $\mathrm{C}_{6} \mathrm{Cl}_{5}$ groups between 270 and $325^{\circ} \mathrm{C}$. Finally, the TGA spectrum of $4 \mathbf{b}$ shows the loss of both $\mathrm{CH}_{3} \mathrm{CN}$ ligands between 100 and $130{ }^{\circ} \mathrm{C}$, and from 200 to $350{ }^{\circ} \mathrm{C}$ the aryl ligands are lost.

From the analysis of these spectra it can be concluded that the thermal stability of the pentachlorophenyl derivatives is higher than that of the $\mathrm{C}_{6} \mathrm{Cl}_{2} \mathrm{~F}_{3}$-substituted compounds and similar to the thermal stability of the previously described pentafluorophenyl complexes [41]. The observed variations in the temperature and percentage of VOC ligands losses are likely due to their different boiling points, the 


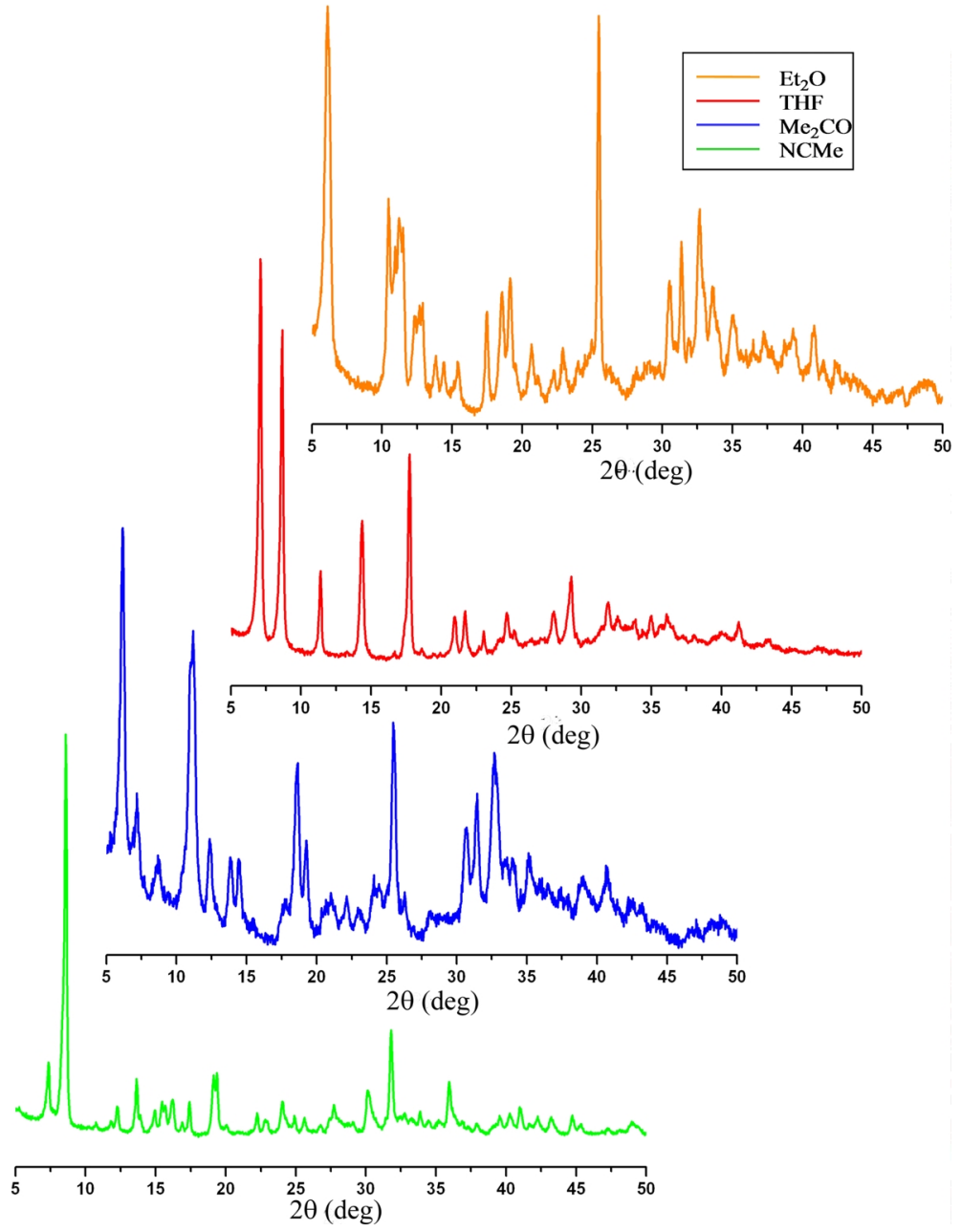

Fig. 6. XPD diffraction patterns for VOC $\mathrm{Au}-\mathrm{Ag}$ materials obtained by treatment of 1b (orange) with THF (red), acetone (blue) and acetonitrile (green) (colour online). strengths of the interactions between the ligands with the silver centres, and the ease of VOC deprotonation (to form volatile $\mathrm{HC}_{6} \mathrm{Cl}_{2} \mathrm{~F}_{3}$ or $\mathrm{HC}_{6} \mathrm{Cl}_{5}$ ).

\section{Powder diffraction studies of the vapochromic materi-} als

$\mathrm{X}$-Ray powder diffraction (XPD) studies of the materials obtained upon exposure of $\left[\mathrm{Au}_{2} \mathrm{Ag}_{2}\left(\mathrm{C}_{6} \mathrm{X}_{5}\right)_{4}\right.$ $\left.\left(\mathrm{Et}_{2} \mathrm{O}\right)_{2}\right]_{n}\left[\mathrm{C}_{6} \mathrm{X}_{5}=\mathrm{C}_{6} \mathrm{Cl}_{2} \mathrm{~F}_{3}(\mathbf{1 a}), \mathrm{C}_{6} \mathrm{Cl}_{5}(\mathbf{1 b})\right]$ to different VOCs (THF, $\mathrm{Me}_{2} \mathrm{CO}, \mathrm{CH}_{3} \mathrm{CN}$ ) were carried out. First, we studied the VOCs uptake ability of diethyl ether complexes $\mathbf{1 a}$ and $\mathbf{1 b}$ by comparison of their XPD profiles with those obtained after exposure of 1a or $\mathbf{1 b}$ to the VOCs mentioned above. Significant differences in the profiles indicate that the substitution of the ether molecules by the different organic molecules has occurred (Figs. 5 and 6). The conclusive proof that the substitution of the $\mathrm{Et}_{2} \mathrm{O}$ molecules is complete and not a surface adsorption process is the match of each profile with that generated from the cif file obtained from the X-ray crystal structure determination. However, this information is only available for complex $\left[\mathrm{Au}_{2} \mathrm{Ag}_{2}\left(\mathrm{C}_{6} \mathrm{Cl}_{2} \mathrm{~F}_{3}\right)_{4}(\mathrm{THF})_{2}\right]_{n}(\mathbf{2 a})$. In this case both $\mathrm{XPD}$ profiles coincide.

We then studied the selectivity and reversibility of the VOCs exchange at r.t. by recording the XPD diffraction patterns of the species resulting from the exposure of each complex to the other three VOCs (Supporting information). As just explained, exposure of 1a to any other VOC leads to the substitution of $\mathrm{Et}_{2} \mathrm{O}$. By contrast, the THF molecules of $\mathbf{2 a}$ are only displaced upon treatment with vapours of acetone, while exposition to acetonitrile gives rise to mixtures, and treatment with $\mathrm{Et}_{2} \mathrm{O}$ does not produce any substitu- 


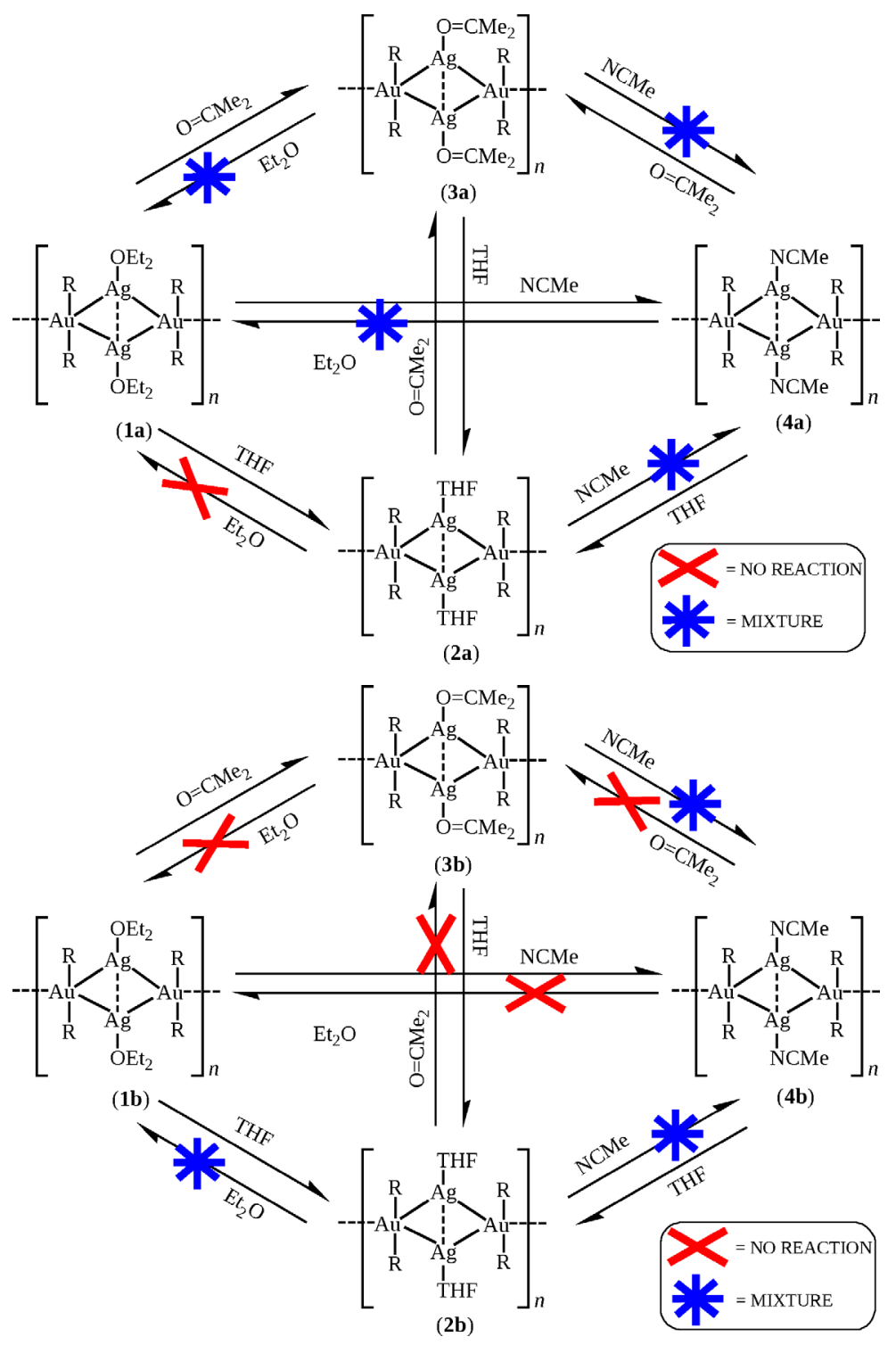

Fig. 7. Vapochromic behaviour of $1 \mathrm{a}-4 \mathrm{a}$.

Fig. 8. Vapochromic behaviour of $1 b-4 b$.

tion (see Fig. 7). In the case of the acetone derivative 3a, neither diethyl ether nor acetonitrile lead to the complete substitution of the organic molecules, resulting in mixtures, and only by exposition to vapours of the $O$-donor molecule THF, the $\mathrm{Me}_{2} \mathrm{CO}$ is replaced by tetrahydrofuran. Finally, the acetonitrile molecules of $\mathbf{4 a}$ can be displaced by vapours of THF or acetone, but $\mathrm{Et}_{2} \mathrm{O}$ does not displace NCMe from the silver centres (Fig. 7). Thus, as in the pentafluorophenyl complexes [41], while diethyl ether can be displaced by the rest of VOCs, this process is not reversible. The fact that $\left[\mathrm{Au}_{2} \mathrm{Ag}_{2}\left(\mathrm{C}_{6} \mathrm{~F}_{3} \mathrm{Cl}_{2}\right)_{4}(\mathrm{NCMe})_{2}\right]_{n}$ (4a) reacts with vapours of acetone and THF, and that acetonitrile does not displace any of these $O$-donor ligands, reveal a different behaviour from that of the $\mathrm{C}_{6} \mathrm{~F}_{5}$ derivatives.

A similar analysis of the vapochromic behaviour of the pentachlorophenyl compounds $\mathbf{1 b}-\mathbf{4 b}$ leads to similar results (Fig. 8), namely that diethyl ether can be replaced by THF, $\mathrm{Me}_{2} \mathrm{CO}$ or NCMe, but again these processes are not completely reversible. Besides, both acetone and acetonitrile are displaced from $\mathbf{3 b}$ and $\mathbf{4 b}$ when treated with THF in processes that are not completely reversible either. Finally, exposition of $\mathbf{3 b}$ to vapours of NCMe leads to a mixture of complexes, 
whereas the XPD pattern of $\mathbf{4 b}$ remains unchanged when exposed to $\mathrm{Me}_{2} \mathrm{CO}$ vapours (see Supporting Information).

\section{FT-IR studies}

Exposure of $\mathbf{1 a}$ or $\mathbf{1 b}$ to $\mathrm{THF}, \mathrm{Me}_{2} \mathrm{CO}$ or $\mathrm{NCMe}$ vapours lead, in all cases, to compounds whose FT-IR spectra clearly show, apart from the bands corresponding to the aryl groups, the characteristic absorptions of the functional groups of the VOCs employed, which appear displaced with respect to those observed for the free VOCs, probably as a consequence of the coordination of the organic molecules to the silver atoms that weakens the $\mathrm{C}-\mathrm{O}$ or $\mathrm{N}-\mathrm{C}$ bonds. This, in agreement with the previously commented XPD results, suggests a complete substitution of the ether molecules in 1a or $\mathbf{1 b}$, resulting in the same species as obtained in solution (2-4). Thus, exposition of $\mathbf{1 a}$ or $\mathbf{1 b}$ to THF affords compounds with $\delta(\mathrm{C}-\mathrm{O}-\mathrm{C})$ at 917 (1a) or 922 (1b) $\mathrm{cm}^{-1}$. When the VOC employed is acetone the products show the $v(\mathrm{C}=\mathrm{O})$ band at 1687 (1a) or 1698 (1b) $\mathrm{cm}^{-1}$, and when NCMe is used the $v(\mathrm{C} \equiv \mathrm{N})$ bands appear at 2305 and 2275 (1a) or at 2304 and 2270 (1b) $\mathrm{cm}^{-1}$.

In this case it is not possible to establish a clear exchange sequence neither according to the donor ability of the VOCs bonded to silver nor to their vapour pressure, since none of these factors seem to have an effect on the susbtitution. However, from the results of our experiments it an be concluded that, as the electronegativity of the halogen atoms present in the aryl group decreases, the strength of the $\mathrm{Ag}-\mathrm{O}$ bond increases, which is in accordance with the Ag-O distance found in the crystal structures of the THF derivatives, which is shorter in the 3,5- $\mathrm{C}_{6} \mathrm{Cl}_{2} \mathrm{~F}_{3}$ complex 2a than in the $\mathrm{C}_{6} \mathrm{~F}_{5}$ complex. The Au-Ag distances are also longer in the $\mathrm{C}_{6} \mathrm{~F}_{5}$ derivative, which seems to indicate a higher donor ability for the bis(aryl) aurate(I) anion in the $3,5-\mathrm{C}_{6} \mathrm{Cl}_{2} \mathrm{~F}_{3}$ complex. Therefore, the substituents present in the aryl groups, and the donor ability of the $\left[\mathrm{Au}\left(\mathrm{C}_{6} \mathrm{X}_{5}\right)_{2}\right]^{-}$anions seem to play the key role.

\section{Experimental Section}

\section{Instrumentation}

Infrared spectra were recorded in the $4000-200 \mathrm{~cm}^{-1}$ range on a Nicolet Nexus FT-IR spectrometer using $\mathrm{Nu}$ jol mulls between polyethylene sheets. $\mathrm{C}, \mathrm{H}$ and $\mathrm{N}$ analyses were carried out with a Perkin-Elmer 240C microanalyser. Mass spectra were recorded on a HP59987 A elec- trospray or a Microflex MALDI-TOF Bruker spectrometer operating in the linear and reflector modes using dithranol as matrix. ${ }^{1} \mathrm{H}$ and ${ }^{19} \mathrm{~F}$ NMR spectra were recorded on a Bruker ARX 300 instrument in $\mathrm{CDCl}_{3}$ solutions at r.t. Chemical shifts are quoted relative to $\mathrm{SiMe}_{4}\left({ }^{1} \mathrm{H}\right.$, external) and $\mathrm{CFCl}_{3}\left({ }^{19} \mathrm{~F}\right.$, external). Absorption spectra in solution were recorded on a Hewlett-Packard 8453 diode array UV/Vis spectrophotometer. Thermogravimetric analyses (TGA) were recorded on a TA Instrument SDT 2960 using 2 - $10 \mathrm{mg}$ samples at a $10{ }^{\circ} \mathrm{C} / \mathrm{min}$ rate between 40 and $600{ }^{\circ} \mathrm{C}$ under nitrogen, and between 600 and $750{ }^{\circ} \mathrm{C}$ in air. X-Ray powder diffraction patterns were obtained at r.t. using a Rigaku D/MAX 2500 X-ray powder diffractometer equipped with graphite-monochromatised $\mathrm{Cu} K_{\alpha}$ radiation operating at $40 \mathrm{kV}$ and $80 \mathrm{~mA}$. Powder diffraction patterns were collected between $2 \theta$ of $5^{\circ}$ and $60^{\circ}$ with a $2 \theta$ stepping angle of $0.03^{\circ}$ and an angle dwell of $1 \mathrm{~s}$.

\section{General Comments}

Complexes $\mathrm{NBu}_{4}\left[\mathrm{AuR}_{2}\right]\left(\mathrm{R}=\mathrm{C}_{6} \mathrm{Cl}_{2} \mathrm{~F}_{3}, \mathrm{C}_{6} \mathrm{Cl}_{5}\right)[43,44]$ were synthesised according to literature procedures, and $\left[\mathrm{Au}_{2} \mathrm{Ag}_{2}\left(\mathrm{C}_{6} \mathrm{Cl}_{5}\right)_{4}\left(\mathrm{Me}_{2} \mathrm{CO}\right)_{2}\right]_{n}$ [45] was obtained following the alternative procedure described below. Solvents used in the spectroscopic studies were degassed prior to use. All the volatile organic compounds are commercially available and were purchased from Panreac. The solid-vapour reactions were carried out at r.t. by passing a stream of nitrogen gas over the liquid VOC and the VOC-saturated nitrogen over the sample.

Synthesis of $\left[\mathrm{Au}_{2} \mathrm{Ag}_{2} \mathrm{R}_{4}\left(\mathrm{OEt}_{2}\right)_{2}\right]_{n}\left[R=3,5-\mathrm{C}_{6} \mathrm{Cl}_{2} \mathrm{~F}_{3}(\mathbf{l a})\right.$, $\left.\mathrm{C}_{6} \mathrm{Cl}_{5}(\mathrm{Ib})\right]$

To a $\mathrm{CH}_{2} \mathrm{Cl}_{2} / \mathrm{Et}_{2} \mathrm{O}$ solution $(1: 2)$ of $\mathrm{NBu}_{4}\left[\mathrm{AuR}_{2}\right](\mathrm{R}=$ 3,5- $\left.\mathrm{Cl}_{2} \mathrm{C}_{6} \mathrm{~F}_{3}, 0.126 \mathrm{~g} ; \mathrm{C}_{6} \mathrm{Cl}_{5}, 0.141 \mathrm{~g}, 0.150 \mathrm{mmol}\right)$ was added $\mathrm{Ag}\left(\mathrm{OClO}_{3}\right)(0.031 \mathrm{~g}, 0.150 \mathrm{mmol})$. An orange (1a) or deep-yellow solid (1b) was immediately formed and filtered after $30 \mathrm{~min}$ of stirring.

1a: Yield: 0.202 g, $87 \%$. - FT-IR (Nujol mull): $v\left(\mathrm{C}_{6} \mathrm{Cl}_{2} \mathrm{~F}_{3}\right)=1588,1557,1057,783 \mathrm{~cm}^{-1} \cdot-{ }^{1} \mathrm{H} \mathrm{NMR}$ (300.13 MHz, $\left.298 \mathrm{~K}, \mathrm{CDCl}_{3}, \mathrm{ppm}\right): \delta=3.37$ (q, $\left.2 \mathrm{H},{ }^{2} J(\mathrm{H}-\mathrm{H})=7 \mathrm{~Hz}, \mathrm{CH}_{2}\right), 1.08\left(\mathrm{t}, 3 \mathrm{H},{ }^{2} J(\mathrm{H}-\mathrm{H})=\right.$ $7 \mathrm{~Hz}, \mathrm{Me}) .-{ }^{19} \mathrm{~F}$ NMR $\left(282.4 \mathrm{MHz}, 298 \mathrm{~K}, \mathrm{CDCl}_{3}\right.$, ppm): $\delta=-88.1\left(\mathrm{~s}, 2 \mathrm{~F}, \mathrm{~F}_{\mathrm{o}}\right),-117.6\left(\mathrm{~s}, 1 \mathrm{~F}, \mathrm{~F}_{\mathrm{p}}\right)$. $\operatorname{MS}((-)-E S): m / z \quad(\%)=596(100) \quad\left[\mathrm{Au}\left(\mathrm{C}_{6} \mathrm{~F}_{3} \mathrm{Cl}_{2}\right)_{2}\right]^{-}$, 1302 (10) $\left(\left[\mathrm{Au}_{2} \mathrm{Ag}\left(\mathrm{C}_{6} \mathrm{~F}_{3} \mathrm{Cl}_{2}\right)_{4}\right]^{-}\right.$. - Elemental anal. for $\mathrm{C}_{32} \mathrm{H}_{20} \mathrm{Au}_{2} \mathrm{Ag}_{2} \mathrm{Cl}_{8} \mathrm{~F}_{12} \mathrm{O}_{2}$ : calcd. C 24.67, $\mathrm{H} \mathrm{1.29}$; found C 24.86, H 1.73 .

1b: Yield: $0.221 \mathrm{~g}, 84 \%$. - FT-IR (Nujol): $v\left(\mathrm{C}_{6} \mathrm{Cl}_{5}\right)=$ 839, $622 \mathrm{~cm}^{-1} .-{ }^{1} \mathrm{H}$ NMR $\left(300.13 \mathrm{MHz}, 298 \mathrm{~K}, \mathrm{CDCl}_{3}\right.$, ppm): $\delta=3.20\left(\mathrm{~m}, 2 \mathrm{H},{ }^{2} J(\mathrm{H}-\mathrm{H})=7 \mathrm{~Hz}, \mathrm{CH}_{2}\right), 1.00(\mathrm{t}, 3 \mathrm{H}$, $\left.{ }^{2} J(\mathrm{H}-\mathrm{H})=7 \mathrm{~Hz}, \mathrm{Me}\right) .-\mathrm{MS}(\mathrm{MALDI}-\mathrm{TOF}(\mathrm{DIT})): \mathrm{m} / \mathrm{z}(\%)=$ 
Table 1. Details of data collection and structure refinement for complexes $\mathbf{2 a}$ and $\mathbf{5 a}$.

\begin{tabular}{|c|c|c|}
\hline Compound & $\mathbf{2 a}$ & $\mathbf{5 a}$ \\
\hline Chemical Formula & $\mathrm{C}_{32} \mathrm{H}_{16} \mathrm{Ag}_{2} \mathrm{Au}_{2-}$ & $\mathrm{C}_{38} \mathrm{H}_{16} \mathrm{Ag}_{2} \mathrm{Au}_{2-}$ \\
\hline & $\mathrm{Cl}_{8} \mathrm{~F}_{12} \mathrm{O}_{2}$ & $\mathrm{Cl}_{8} \mathrm{~F}_{12} \cdot \mathrm{C}_{7} \mathrm{H}_{8}$ \\
\hline Crystal colour & orange & yellow \\
\hline Crystal size, $\mathrm{mm}^{3}$ & $0.2 \times 0.08 \times 0.08$ & $0.45 \times 0.07 \times 0.07$ \\
\hline Crystal system & monoclinic & monoclinic \\
\hline Space group & $C 2 / c$ & $C 2 / c$ \\
\hline$a, \AA$ & $22.4647(5)$ & $27.0403(4)$ \\
\hline$b, \AA$ & $14.7540(3)$ & $7.4579(1)$ \\
\hline$c, \AA$ & $25.4170(6)$ & $23.8375(4)$ \\
\hline$\beta, \operatorname{deg}$ & $106.890(1)$ & $102.5885(6)$ \\
\hline$V, \AA^{3}$ & $1048.54(5)$ & $4691.60(12)$ \\
\hline$Z$ & 8 & 4 \\
\hline$D c, \mathrm{~g} \mathrm{~cm}^{-3}$ & 2.56 & 2.38 \\
\hline$F(000), \mathrm{e}$ & 5760 & 3148 \\
\hline$T, \mathrm{~K}$ & $173(2)$ & $173(2)$ \\
\hline $2 \theta_{\max }, \mathrm{deg}$ & 56 & 59 \\
\hline$\mu\left(\mathrm{Mo} K_{\alpha}\right), \mathrm{mm}^{-1}$ & 8.8 & 14.2 \\
\hline Refl. measured / unique & $31188 / 9585$ & $35532 / 5780$ \\
\hline$R_{\text {int }}$ & 0.0672 & 0.0558 \\
\hline Refined parameters & 525 & 329 \\
\hline Restraints & 156 & 102 \\
\hline$R^{\mathrm{a}}[I \geq 2 \sigma(I)]$ & 0.0531 & 0.0307 \\
\hline$w R^{\mathrm{b}}\left(F^{2}\right.$, all refl. $)$ & 0.1559 & 0.0692 \\
\hline$S^{\mathrm{c}}$ & 1.038 & 1.036 \\
\hline $\begin{array}{l}\text { Max. residual electron } \\
\text { density, e } \AA^{-3}\end{array}$ & 3.34 & 1.35 \\
\hline \multicolumn{3}{|c|}{$\begin{array}{l}\text { a } R(F)=\Sigma|| F_{\mathrm{o}}|-| F_{\mathrm{c}}|| / \Sigma\left|F_{\mathrm{o}}\right| ;{ }^{\mathrm{b}} w R\left(F^{2}\right)=\left[\Sigma\left\{w\left(F_{\mathrm{o}}{ }^{2}-F_{\mathrm{c}}{ }^{2}\right)^{2}\right\} /\right. \\
\Sigma\left\{w\left(F_{\mathrm{o}}{ }^{2}\right\}\right]^{0.5}, w^{-1}=\sigma^{2}\left(F_{\mathrm{o}}{ }^{2}\right)+(a P)^{2}+b P, \text { where } P=\left[F_{\mathrm{o}}{ }^{2}+\right. \\
\left.2 F_{\mathrm{c}}{ }^{2}\right] / 3 \text { and } a \text { and } b \text { are constants adjusted by the program; }{ }^{\mathrm{c}} S= \\
\mathrm{GoF}=\left[\Sigma\left\{w\left(F_{\mathrm{o}}{ }^{2}-F_{\mathrm{c}}{ }^{2}\right)^{2}\right\} /(n-p)\right]^{0.5} \text {, where } n \text { is the number of data } \\
\text { and } p \text { the number of parameters. }\end{array}$} \\
\hline
\end{tabular}

$695(100)\left[\mathrm{Au}\left(\mathrm{C}_{6} \mathrm{Cl}_{5}\right)_{2}\right]^{-}, 1142(25)\left[\mathrm{Au}_{2}\left(\mathrm{C}_{6} \mathrm{Cl}_{5}\right)_{3}\right]^{-} .-\mathrm{El}-$ emental anal. for $\mathrm{C}_{32} \mathrm{H}_{20} \mathrm{Au}_{2} \mathrm{Ag}_{2} \mathrm{Cl}_{20} \mathrm{O}_{2}$ : calcd. C 21.90, $\mathrm{H} 1.15$; found C 21.92, H 1.12.

Synthesis of $\left[\mathrm{Au}_{2} \mathrm{Ag}_{2} \mathrm{R}_{4} L_{2}\right]_{n}\left[R=3,5-\mathrm{C}_{6} \mathrm{Cl}_{2} \mathrm{~F}_{3}, L=T H F\right.$ (2a), $\mathrm{Me}_{2} \mathrm{CO}(\mathbf{3 a}), \mathrm{NCMe}(\mathbf{4 a}), \eta^{2}-\mathrm{C}_{7} \mathrm{H}_{8}(\mathbf{5 a}) ; \mathrm{R}=\mathrm{C}_{6} \mathrm{Cl}_{5}$, $\left.L=\operatorname{THF}(2 \boldsymbol{b}), \mathrm{Me}_{2} \mathrm{CO}(3 \boldsymbol{b}), N C M e(4 \boldsymbol{b}), \eta^{2}-C_{7} H_{8}(5 \boldsymbol{b})\right]$

A solution of 1a $(0.156 \mathrm{~g}, 0.150 \mathrm{mmol})$ in THF (2a), $\mathrm{NCMe}(\mathbf{4 a})$ or a suspension in $\mathrm{Me}_{2} \mathrm{CO}(\mathbf{3 a})$ or toluene $(\mathbf{5 a})$ or a suspension of $\mathbf{1 b}(0.176 \mathrm{~g}, 0.1 \mathrm{mmol})$ in $\operatorname{THF}(\mathbf{2 b})$, acetone $(\mathbf{3 b})$, acetonitrile $(\mathbf{4 b})$ or toluene $(\mathbf{5 b})(15 \mathrm{~mL})$ was stirred for $15 \mathrm{~min}$. Evaporation of the solvent to dryness gave an orange (2a, 3a, 5a), yellow $(\mathbf{4 a}, \mathbf{5 b})$ deep-red $(\mathbf{2 b}, \mathbf{3 b})$ or white (4b) solid in an almost quantitative yield.

2a: FT-IR (Nujol mull): $v\left(\mathrm{C}_{6} \mathrm{Cl}_{2} \mathrm{~F}_{3}\right)=1588,1557,1060$, $784 \mathrm{~cm}^{-1} ; v(\mathrm{C}-\mathrm{O}-\mathrm{C})=917 \mathrm{~cm}^{-1} .-{ }^{1} \mathrm{H}$ NMR $(300.13 \mathrm{MHz}$, $\left.298 \mathrm{~K}, \mathrm{CDCl}_{3}, \mathrm{ppm}\right): \delta=3.65\left(\mathrm{~m}, 2 \mathrm{H}, \mathrm{CH}_{2} \mathrm{O}\right), 1.74$ $\left(\mathrm{m}, 2 \mathrm{H}, \mathrm{CH}_{2}\right) .-{ }^{19} \mathrm{~F}$ NMR $\left(282.4 \mathrm{MHz}, 298 \mathrm{~K}, \mathrm{CDCl}_{3}\right.$, ppm): $\delta=-88.1\left(\mathrm{~s}, 2 \mathrm{~F}, \mathrm{~F}_{\mathrm{o}}\right),-117.5\left(\mathrm{~s}, 1 \mathrm{~F}, \mathrm{~F}_{\mathrm{p}}\right)$. MS ((+)-ES): $m / z(\%)=507$ (45) $\left[\mathrm{AuAg}\left(\mathrm{C}_{6} \mathrm{Cl}_{2} \mathrm{~F}_{3}\right)\right]^{+}$. MS ((-)-ES): $m / z \quad(\%)=597\left[\mathrm{Au}\left(\mathrm{C}_{6} \mathrm{Cl}_{2} \mathrm{~F}_{3}\right)_{2}\right]^{-}$(59), 1301 (100) $\left(\left[\mathrm{Au}_{2} \mathrm{Ag}\left(\mathrm{C}_{6} \mathrm{Cl}_{2} \mathrm{~F}_{3}\right)_{4}\right]^{-}\right.$. - Elemental anal. for
Table 2. Selected bond lengths $(\AA)$ and angles (deg) for complex $2 \mathrm{a}^{\mathrm{a}}$.

\begin{tabular}{llll}
\hline $\mathrm{Au}(1)-\mathrm{C}(1)$ & $2.076(7)$ & $\mathrm{Au}(3)-\mathrm{Au}(4)$ & $2.8617(7)$ \\
$\mathrm{Au}(2)-\mathrm{C}(11)$ & $2.079(8)$ & $\mathrm{Au}(1)-\mathrm{Ag}(1)$ & $2.7505(8)$ \\
$\mathrm{Au}(3)-\mathrm{C}(21)$ & $2.071(8)$ & $\mathrm{Au}(2)-\mathrm{Ag}(2)$ & $2.7172(8)$ \\
$\mathrm{Au}(4)-\mathrm{C}(31)$ & $2.052(8)$ & $\mathrm{Au}(3)-\mathrm{Ag}(2)$ & $2.7629(8)$ \\
$\mathrm{Ag}(1)-\mathrm{O}(1)$ & $2.284(8)$ & $\mathrm{Au}(4)-\mathrm{Ag}(1)^{\# 2}$ & $2.7144(8)$ \\
$\mathrm{Ag}(2)-\mathrm{O}(2)$ & $2.286(8)$ & $\mathrm{Ag}(1)-\mathrm{Ag}(1)^{\# 1}$ & $3.0700(14)$ \\
$\mathrm{Au}(1)-\mathrm{Au}(2)$ & $2.8863(7)$ & $\mathrm{Ag}(2)-\mathrm{Ag}(2)^{\# 1}$ & $3.1487(14)$ \\
$\mathrm{C}(1)-\mathrm{Au}(1)-\mathrm{C}(1)^{\# 1}$ & $178.5(4)$ & $\mathrm{C}(21)-\mathrm{Au}(3)-\mathrm{C}(21)^{\# 1}$ & $179.5(4)$ \\
$\mathrm{C}(11)-\mathrm{Au}(2)-\mathrm{C}(11)^{\# 1}$ & $176.6(4)$ & $\mathrm{C}(31)-\mathrm{Au}(4)-\mathrm{C}(31)^{\# 1}$ & $174.7(4)$ \\
\hline
\end{tabular}

a Symmetry transformations used to generate equivalent atoms: $\# 1-x+1, y,-z+1 / 2 ;{ }^{\# 2}-x+1, y+1,-z+1 / 2 ;{ }^{\# 3} x, y+1, z$; ${ }^{\# 4} x, y-1, z$.

Table 3. Selected bond lengths ( $\mathrm{A})$ and angles (deg) for complex $5 \mathbf{a}^{\mathrm{a}}$.

\begin{tabular}{llll}
\hline $\mathrm{Au}(1)-\mathrm{C}(1)$ & $2.055(4)$ & $\mathrm{Au}(1)-\mathrm{Au}(2)$ & $2.9092(3)$ \\
$\mathrm{Au}(2)-\mathrm{C}(11)$ & $2.056(4)$ & $\mathrm{Au}(1)-\mathrm{Ag}$ & $2.7003(4)$ \\
$\mathrm{Ag}-\mathrm{C}(21)$ & $2.534(5)$ & $\mathrm{Au}(2)-\mathrm{Ag}^{\# 2}$ & $2.7710(4)$ \\
$\mathrm{Ag}-\mathrm{C}(22)$ & $2.422(4)$ & $\mathrm{Ag}-\mathrm{Ag}{ }^{\# 1}$ & $3.0401(7)$ \\
$\mathrm{C}(1)-\mathrm{Au}(1)-\mathrm{C}(1)^{\# 1}$ & $174.6(2)$ & $\mathrm{C}(11)-\mathrm{Au}(2)-\mathrm{C}(11)^{\# 1}$ & $178.40(19)$
\end{tabular}

a Symmetry transformations used to generate equivalent atoms: ${ }^{\# 1}$ $-x, y,-z+1 / 2{ }^{\# 2} x, y+1, z ;{ }^{\# 3}-x, y+1,-z+1 / 2 ;{ }^{\# 4} x, y-1, z$.

$\mathrm{C}_{32} \mathrm{H}_{16} \mathrm{Au}_{2} \mathrm{Ag}_{2} \mathrm{Cl}_{8} \mathrm{~F}_{12} \mathrm{O}_{2}$ : calcd. C 24.74, $\mathrm{H}$ 1.03; found C 24.59, H 0.79 .

2b: FT-IR (Nujol mull): $v\left(\mathrm{C}_{6} \mathrm{Cl}_{5}\right)=837,621 \mathrm{~cm}^{-1}$; $v(\mathrm{C}-\mathrm{O}-\mathrm{C})=922 \mathrm{~cm}^{-1} .-{ }^{1} \mathrm{H}$ NMR $(300.13 \mathrm{MHz}, 298 \mathrm{~K}$, $\left.\mathrm{CDCl}_{3}, \mathrm{ppm}\right): \delta=3.73\left(\mathrm{~m}, 2 \mathrm{H}, \mathrm{CH}_{2} \mathrm{O}\right), 1.84(\mathrm{~m}, 2 \mathrm{H}$, $\mathrm{CH}_{2}$ ). - MS (MALDI-TOF (DIT)): $\mathrm{m} / \mathrm{z}(\%)=695(100)$ $\left[\mathrm{Au}\left(\mathrm{C}_{6} \mathrm{Cl}_{5}\right)_{2}\right]^{-}, 1449$ (21) $\left[\mathrm{Au}_{2} \mathrm{Ag}\left(\mathrm{C}_{6} \mathrm{Cl}_{5}\right)_{4}\right]^{-}$. - Elemental anal. for $\mathrm{C}_{32} \mathrm{H}_{16} \mathrm{Au}_{2} \mathrm{Ag}_{2} \mathrm{Cl}_{20} \mathrm{O}_{2}$ : calcd. C 21.95, $\mathrm{H} 0.92$; found $\mathrm{C} 22.02, \mathrm{H} 0.89$.

3a: FT-IR (Nujol mull): $v\left(\mathrm{C}_{6} \mathrm{Cl}_{2} \mathrm{~F}_{3}\right)=1589,1558,1061$, $784 \mathrm{~cm}^{-1} ; v(\mathrm{C}=\mathrm{O})=1687 \mathrm{~cm}^{-1} .-{ }^{1} \mathrm{H}$ NMR $(300.13 \mathrm{MHz}$, $\left.298 \mathrm{~K}, \mathrm{CDCl}_{3}, \mathrm{ppm}\right): \delta=2.14\left(\mathrm{~s}, 3 \mathrm{H}, \mathrm{CH}_{3}\right) .-{ }^{19} \mathrm{~F} \mathrm{NMR}$ $\left(282.4 \mathrm{MHz}, 298 \mathrm{~K}, \mathrm{CDCl}_{3}, \mathrm{ppm}\right): \delta=-88.2\left(\mathrm{~s}, 2 \mathrm{~F}, \mathrm{~F}_{\mathrm{o}}\right.$ ), $-117.8\left(\mathrm{~s}, 1 \mathrm{~F}, \mathrm{~F}_{\mathrm{p}}\right) .-\mathrm{MS}((-)-\mathrm{ES}): m / z(\%)=600(100)$ $\left[\mathrm{Au}\left(\mathrm{C}_{6} \mathrm{Cl}_{2} \mathrm{~F}_{3}\right)_{2}\right]^{-}, 1302$ (35) $\left[\mathrm{Au}_{2} \mathrm{Ag}\left(\mathrm{C}_{6} \mathrm{Cl}_{2} \mathrm{~F}{ }_{3}\right)_{4}\right]^{-}$. - Elemental anal. for $\mathrm{C}_{30} \mathrm{H}_{12} \mathrm{Au}_{2} \mathrm{Ag}_{2} \mathrm{Cl}_{8} \mathrm{~F}_{12} \mathrm{O}_{2}$ : calcd. C 23.61, $\mathrm{H}$ 0.78; found C 23.50, H 0.60.

3b: FT-IR (Nujol mull): $v\left(\mathrm{C}_{6} \mathrm{Cl}_{5}\right)=837,624 \mathrm{~cm}^{-1}$; $v(\mathrm{C}=\mathrm{O})=1695 \mathrm{~cm}^{-1} \cdot-{ }^{1} \mathrm{H}$ NMR $(300.13 \mathrm{MHz}, 298 \mathrm{~K}$, $\mathrm{CDCl}_{3}, \mathrm{ppm}$ ): $\delta=2.16$ (s, 3H, $\mathrm{CH}_{3}$ ). - MS (MALDI-TOF (DIT)): $m / z(\%)=695(100)\left[\mathrm{Au}\left(\mathrm{C}_{6} \mathrm{Cl}_{5}\right)_{2}\right]^{-}$. - Elemental

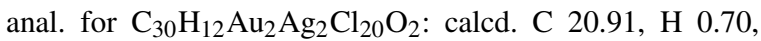
found $\mathrm{C} 20.32, \mathrm{H} 0.68$.

4a: FT-IR (Nujol mull): $v\left(\mathrm{C}_{6} \mathrm{Cl}_{2} \mathrm{~F}_{3}\right)=1590,1558,1060$, $784 \mathrm{~cm}^{-1} ; \quad v(\mathrm{C} \equiv \mathrm{N})=2305,2275 \mathrm{~cm}^{-1} .-{ }^{1} \mathrm{H} \mathrm{NMR}$ (300.13 MHz, $298 \mathrm{~K}, \mathrm{CDCl}_{3}$, ppm): $\delta=2.00$ (s, 3H, $\mathrm{CH}_{3}$ ). ${ }^{19} \mathrm{~F}$ NMR $\left(282.4 \mathrm{MHz}, 298 \mathrm{~K}, \mathrm{CDCl}_{3}, \mathrm{ppm}\right): \delta=-88.1(\mathrm{~s}$, $\left.2 \mathrm{~F}, \mathrm{~F}_{\mathrm{o}}\right),-117.6\left(\mathrm{~s}, 1 \mathrm{~F}, \mathrm{~F}_{\mathrm{p}}\right) .-\mathrm{MS}((-)-\mathrm{ES}): \mathrm{m} / z(\%)=600$ (100) $\left[\mathrm{Au}\left(\mathrm{C}_{6} \mathrm{Cl}_{2} \mathrm{~F}_{3}\right)_{2}\right]^{-}, 1302$ (25) $\left[\mathrm{Au}_{2} \mathrm{Ag}\left(\mathrm{C}_{6} \mathrm{Cl}_{2} \mathrm{~F}_{3}\right)_{4}\right]^{-}$. $\Lambda_{\mathrm{M}}$ (acetonitrile): $124.9 \mathrm{~mol}^{-1} \mathrm{~cm}^{2} \Omega^{-1}(1: 1)$. Elemental 
anal. for $\mathrm{C}_{28} \mathrm{H}_{6} \mathrm{Au}_{2} \mathrm{Ag}_{2} \mathrm{Cl}_{8} \mathrm{~F}_{12} \mathrm{~N}_{2}$ : calcd. C 22.55, $\mathrm{H} \mathrm{0.40,}$ $\mathrm{N} 1.88$; found $\mathrm{C} 22.73, \mathrm{H} 0.60, \mathrm{~N} 1.64$.

4b: FT-IR (Nujol mull): $v\left(\mathrm{C}_{6} \mathrm{Cl}_{5}\right)=838,615 \mathrm{~cm}^{-1}$; $v(\mathrm{C} \equiv \mathrm{N})=2304,2270 \mathrm{~cm}^{-1} \cdot-{ }^{1} \mathrm{H}$ NMR $(300.13 \mathrm{MHz}$, $298 \mathrm{~K}, \mathrm{CDCl}_{3}$, ppm): $\delta=2.20\left(\mathrm{~s}, 3 \mathrm{H}, \mathrm{CH}_{3}\right)$. - MS (MALDITOF (DIT)): $m / z(\%)=695(100)\left[\mathrm{Au}\left(\mathrm{C}_{6} \mathrm{Cl}_{5}\right)_{2}\right]^{-}$. - Elemen-

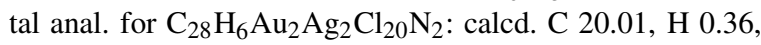
$\mathrm{N}$ 1.67; found C 19.91, H 0.36, N 1.66.

5a: FT-IR (Nujol mull): $v\left(\mathrm{C}_{6} \mathrm{Cl}_{2} \mathrm{~F}_{3}\right)=1590,1558$, $1058,781 \mathrm{~cm}^{-1} ; v\left(\mathrm{C}_{7} \mathrm{H}_{8}\right)=760,693 \mathrm{~cm}^{-1} .-{ }^{1} \mathrm{H} \mathrm{NMR}$ $\left(300.13 \mathrm{MHz}, 298 \mathrm{~K}, \mathrm{CDCl}_{3}, \mathrm{ppm}\right): \delta=7.25(\mathrm{~m}$, $\left.2 \mathrm{H}, \mathrm{H}_{m}\right), 7.18\left(\mathrm{~m}, 3 \mathrm{H}, \mathrm{H}_{o / p}\right), 2.34\left(\mathrm{~s}, 3 \mathrm{H}, \mathrm{CH}_{3}\right)$. ${ }^{19} \mathrm{~F}$ NMR $\left(282.4 \mathrm{MHz}, 298 \mathrm{~K}, \mathrm{CDCl}_{3}, \mathrm{ppm}\right): \delta=-88.1$ $\left(\mathrm{s}, 2 \mathrm{~F}, \mathrm{~F}_{\mathrm{o}}\right),-117.6\left(\mathrm{~s}, 1 \mathrm{~F}, \mathrm{~F}_{\mathrm{p}}\right) .-\mathrm{MS}((-)-\mathrm{ES}): \mathrm{m} / \mathrm{z}$ $(\%)=600$ (100) $\left[\mathrm{Au}\left(\mathrm{C}_{6} \mathrm{Cl}_{2} \mathrm{~F}_{3}\right)_{2}\right]^{-}$. - Elemental anal. for $\mathrm{C}_{38} \mathrm{H}_{16} \mathrm{Au}_{2} \mathrm{Ag}_{2} \mathrm{Cl}_{8} \mathrm{~F}_{12}$ : calcd. C 28.64, H 1.01; found C 29.69, H 1.14.

5b: FT-IR (Nujol mull): $v\left(\mathrm{C}_{6} \mathrm{Cl}_{5}\right)=838,621 \mathrm{~cm}^{-1}$; $v\left(\mathrm{C}_{7} \mathrm{H}_{8}\right)=765,702 \mathrm{~cm}^{-1} .-{ }^{1} \mathrm{H}$ NMR $(300.13 \mathrm{MHz}, 298 \mathrm{~K}$, $\left.\mathrm{CDCl}_{3}, \mathrm{ppm}\right): \delta=7.22\left(\mathrm{~m}, 2 \mathrm{H}, \mathrm{H}_{m}\right), 7.17\left(\mathrm{~m}, 3 \mathrm{H}, \mathrm{H}_{o / p}\right)$, 2.34 (s, 3H, $\mathrm{CH}_{3}$ ). - MS (MALDI-TOF (DIT)): $\mathrm{m} / \mathrm{z}(\%)=$ 695 (100) $\left[\mathrm{Au}\left(\mathrm{C}_{6} \mathrm{Cl}_{5}\right)_{2}\right]^{-}, 1449$ (5) $\left[\mathrm{Au}_{2} \mathrm{Ag}\left(\mathrm{C}_{6} \mathrm{Cl}_{5}\right)_{4}\right]^{-}$. Elemental anal. for $\mathrm{C}_{38} \mathrm{H}_{16} \mathrm{Au}_{2} \mathrm{Ag}_{2} \mathrm{Cl}_{20}$ : calcd. C 25.48, $\mathrm{H} 0.90$; found C 25.57, H 0.92 .

Crystal structure analyses

Crystals were mounted in inert oil on glass fibers and transferrred to the cold gas stream of a Nonius Kappa CCD diffractometer equipped with an Oxford Instruments lowtemperature attachment. Data were collected using graphitemonochromatised $\operatorname{Mo} K_{\alpha}$ radiation $(\lambda=0.71073 \AA)$. Scan type: $\omega$ and $\phi$. Absorption corrections: numerical (based on multiple scans). The structures were solved by Direct Methods and refined on $F^{2}$ using SHELXS/L-97 [46]. All non-hydrogen atoms were refined anisotropically. Hydrogen atoms were included using a riding model. The methyl group of the coordinated toluene molecules in 5a are disordered over two different positions $(50: 50)$. Further details of the data collection and refinement are given in Table 1. Selected bond lengths and angles are collected in Tables 2 and 3.

CCDC 747549 and 747550 contain the supplementary crystallographic data for this paper. These data can be obtained free of charge via www.ccdc.cam.ac.uk/data_request /cif.

\section{Supporting Information}

XPD diffraction patterns of the species resulting from the exposure of each complex to the other three VOCs (Figs. S1 and S2) are available as Supporting Information (online only).

\section{Acknowledgements}

This work was supported by the D. G. I.(MEC)/FEDER (CTQ2007-67273-C02-02). R. C. P. thanks the Spanish MEC for a grant.
[1] H. Schmidbaur, W. Graf, G. Müller, Angew. Chem. 1988, 100, 439-441; Angew. Chem., Int. Ed. Engl. 1988, 27, $417-419$.

[2] P. Pyykkö, Chem. Rev. 1997, 97, 597-636.

[3] a) H.H. Karsch, U. Schubert, Z. Naturforsch. 1982, 37b, 186; b) T. Tsuda, S. Ohba, M. Takahashi, M. Ito, Acta Crystallogr. 1989, C 45, 887-890; c) M. Jansen, Angew. Chem. 1987, 99, 1136-1149; Angew. Chem., Int. Ed. Engl. 1987, 26, $1098-1110$.

[4] A. Heine, R. Herbst-Irmer, D. Stalke, J. Chem. Soc., Chem. Commun. 1993, 1729-1731.

[5] H. Schmidbaur, H.-J. Öller, D. L. Wilkinson, B. Huber, G. Müller, Chem. Ber. 1989, 122, 31-36.

[6] S. Otsuka, J. Organomet. Chem. 1980, 200, 191-205.

[7] Y. Pan, J. T. Mage, M. J. Fink, J. Am. Chem. Soc. 1993, $115,3842-3843$.

[8] a) T. Tanase, Y. Kudo, M. Ohno, K. Kobayashi, Y. Yamamoto, Nature 1990, 344, 526; b) N. M. Boag, M. Green, J. A. K. Howard, F. G. A. Stone, H. Wadepohl, J. Chem. Soc., Dalton Trans. 1981, $862-$ 872.

[9] a) R. Blom, H. Werner, J. Wolf, J. Organomet. Chem. 1988, 354, 293-299; b) H. Pritzkow, P. Jennische, Acta Chem. Scand. 1975, A29, 60-70; c) B. Krebs,
H. Greiwing, Z. Anorg. Allg. Chem. 1992, 616, $145-153$.

[10] L. A. Bengtsson, R. Hoffmann, J. Am. Chem. Soc. 1993, 115, 2666-2676.

[11] J. K. Nagle, A. L. Balch, M. M. Olmstead, J. Am Chem. Soc. 1988, 110, 319-321.

[12] A. L. Balch, B. J. Davis, E. Y. Fung, M. M. Olmstead, Inorg. Chim. Acta 1993, 212, 149-156.

[13] A. L. Balch, J. K. Nagle, M. M. Olmstead, P. E. Reedy, Jr., J. Am. Chem. Soc. 1987, 109, 4123 - 4124.

[14] S. Wang, J. P. Fackler, Jr., C. King, J. C. Wang, J. Am. Chem. Soc. 1988, 110, 3308-3310.

[15] S. Wang, G. Garzon, C. King, J. C. Wang, J. P. Fackler, Jr., Inorg. Chem. 1989, 28, 4623-4629.

[16] J. C. Jeffery, P. A. Jelliss, F. G. A. Stone, Inorg. Chem. 1993, 32, 3943 - 3947.

[17] T. F. Carlson, J.P. Fackler, Jr., R. J. Staples, R. E. P. Winpenny, Inorg. Chem. 1995, 34, 426-431.

[18] H.-K. Yip, H.-M. Lin, Y. Wang, C.-M. Che, J. Chem. Soc., Dalton Trans. 1993, 2939-2944.

[19] O. Crespo, A. Laguna, E. J. Fernández, J. M. Lópezde-Luzuriaga, P. G. Jones, M. Teichert, M. Monge, P. Pyykkö, N. Runeberg, M. Schütz, H.-J. Werner, Inorg. Chem. 2000, 39, 4786-4792. 
[20] E. J. Fernández, J. M. López-de-Luzuriaga, M. Monge, M. A. Rodríguez, O. Crespo, M. C. Gimeno, A. Laguna, P. G. Jones, Chem. Eur. J. 2000, 6, 636644.

[21] J. M. López-de-Luzuriaga in Modern supramolecular gold chemistry; gold-metal interactions and applications (Ed.: A. Laguna), Wiley-VCH, Weinheim, 2008, chapter 6, pp. $347-401$.

[22] L. G. Beauvais, M. P. Shores, J. R. Long, J. Am. Chem. Soc. 2000, 122, $2763-2772$.

[23] a) Q. Chang, Z. Murtaza, J. R. Lakowicz, G. Rao, Anal. Chim. Acta 1997, 350, 97 - 104; b) C. J. Murphy, W. D. Drane, Proc. SPIE - Int. Soc. Opt. Eng. 1995, 2388, 266; c) C. A. Bignozzi, C. Chiorboli, M. T. Indelli, M. A. Rampi Scandola, G. Varani, F. Scandola, J. Am. Chem. Soc. 1986, 108, 7872-7873; d) J.R. Winkler, C. Creutz, N. Sutin, J. Am. Chem. Soc. 1987, 109, 3470-3471; e) F. Scandola, M. T. Indelli, Pure Appl. Chem. 1988, 60, $973-980 ;$ f) M. Kato, S. Yamauchi, N. Hirota, J. Phys. Chem. 1989, 93, $3422-$ 3425; g) M.E.G. Poss, N.E. Katz, L. M. Baraldo, D. D. Polonuer, C. G. Colombano, J. A. Olabe, Inorg. Chem. 1995, 34, 1830 - 1835; h) E. Waldhör, J. Poppe, W. Kaim, E. H. Cutin, M. E. G. Posse, N. E. Kartz, Inorg. Chem. 1995, 34, $3093-3096$; i) A.C. Samuels, M. K. DeArmond, Inorg. Chem. 1995, 34, 5548 - 5551; j) C. J. Timpson, C. A. Bignozzi, B. P. Sullivan, E. M. Kober, T. J. Meyer, J. Phys. Chem. 1996, 100, 2915 2925; k) M. A. Rampi, M. T. Indelli, F. Scandola, F. Pina, A. J. Parola, Inorg. Chem. 1996, 35, $3355-$ 3361.

[24] J. K. Evju, K. R. Mann, Chem. Mater. 1999, 11, 1425 1433.

[25] E. A. Baldauff, J. M. Buriak, Chem. Commun. 2004, $2028-2029$.

[26] a) W. Lu, M. C. W. Chan, N. Zhu, C.-M. Che, Z. He, K.-Y. Wong, Chem. Eur. J. 2003, 9, 6155-6166; b) S. M. Drew, D. E. Janzen, C. E. Buss, D. I. MacEwan, K. M. Dublin, K. R. Mann, J. Am. Chem. Soc. 2001, 123, 8414-8415.

[27] C. E. Buss, K. R. Mann, J. Am. Chem. Soc. 2002, 124, $1031-1039$.

[28] a) J. W. Grate, L. K. Moore, D. E. Janzen, D. J. Veltkamp, S. Kaganove, S. M. Drew, K. R. Mann, Chem. Mater. 2002, 14, 1058 - 1066; b) C. L. Exstrom, J. R. Sowa, Jr., C. A. Daws, D. Janzen, K. R. Mann, G. A. Moore, F. F. Stewart, Chem. Mater. 1995, 7, 1517; c) C. A. Daws, C. L. Exstrom, J. R. Sowa, Jr., K. R. Mann, Chem. Mater. 1997, 9, 363 -368; d) C. E. Buss, C. E. Anderson, M. K. Pomije, C. M. Lutz, D. Britton, K. R. Mann, J. Am. Chem. Soc. 1998, 120, 7783 - 7790; e) C.L. Exstrom, M. K. Pomije, K. R. Mann, Chem. Mater. 1998, 10, $942-945$.

[29] H. V.R. Dias, H.V. K. Diyabalanage, M.A.
Rawashdeh-Omary, M. A. Franzman, M. A. Omary, J. Am. Chem. Soc. 2003, 125, $12072-12073$.

[30] E. Cariati, X. Bu, P.C. Ford, Chem. Mater. 2000, 12, $3385-3391$.

[31] a) R. L. White-Morris, M. M. Olmstead, F. Jiang, D. S. Tinti, A. L. Balch, J. Am. Chem. Soc. 2002, 124, 2327 2336; b) J. C.Vickery, M. M. Olmstead, E. Y. Fung, A. L. Balch, Angew. Chem. 1997, 109, 1227-1229; Angew. Chem., Int. Ed. Engl. 1997, 36, 1179-1181; c) E. Y. Fung, M. M. Olmstead, J.C. Vickery, A. L. Balch, Coord. Chem. Rev. 1998, 171, $151-159$.

[32] M. A. Mansour, W. B. Connick, R. J. Lachicotte, H. J. Gysling, R. Eisenberg, J. Am. Chem. Soc. 1998, 120, $1329-1330$.

[33] a) E. J. Fernández, J. M. López-de-Luzuriaga, M. Monge, M.E. Olmos, J. Pérez, A. Laguna, A. A. Mohamed, J. P. Fackler, Jr., J. Am. Chem. Soc. 2003, 125, 2022-2023; b) E. J. Fernández, J. M. Lópezde-Luzuriaga, M. Monge, M. Montiel, M.E. Olmos, J. Pérez, A. Laguna, F. Mendizábal, A. A. Mohamed, J. P. Fackler, Jr., Inorg. Chem. 2004, 43, $3573-$ 3581.

[34] J. Lefebvre, R. J. Batchelor, D. B. Leznoff, J. Am. Chem. Soc. 2004, 126, $16117-16125$.

[35] a) M. A. Rawashdeh-Omary, M. A. Omary, J. P. Fackler, Jr., Inorg. Chim. Acta 2002, 334, 376-384; b) O. Crespo, E. J. Fernández, M. Gil, M. C. Gimeno, P. G. Jones, A. Laguna, J. M. López-de-Luzuriaga, M.E. Olmos, J. Chem. Soc., Dalton Trans. 2002, 1319-1326; c) V. J. Catalano, S. J. Horner, Inorg. Chem. 2003, 42, 8430-8438; d) V. J. Catalano, M. A. Malwitz, A. O. Etogo, Inorg. Chem. 2004, 43, $5714-$ 5724; e) P. Römbke, A. Schier, H. Schmidbaur, S. Cronje, H. Raubenheimer, Inorg. Chim. Acta 2004, $357,235-242$.

[36] a) M.E. Olmos, A. Schier, H. Schmidbaur, Z. Naturforsch. 1997, 52b, 203-208; b) J. Vicente, M. T. Chicote, M. C. Lagunas, P. G. Jones, J. Chem. Soc., Chem. Commun. 1991, 1730-1731; c) J. Vicente, M. T. Chicote, M. C. Lagunas, Inorg. Chem. 1993, 32, $3748-3754$.

[37] a) R. Usón, A. Laguna, M. Laguna, P. G. Jones, G. M. Sheldrick, J. Chem. Soc., Chem. Commun. 1981, 1097 -1098; b) R. Usón, A. Laguna, M. Laguna, B. R. Manzano, P. G. Jones, G. M. Sheldrick, J. Chem. Soc., Dalton Trans 1984, 285-292; c) E. J. Fernández, M. C. Gimeno, A. Laguna, J. M. López-de-Luzuriaga, M. Monge, P. Pyykkö, D. Sundholm, J. Am. Chem. Soc. 2000, 122, 7287-7293.

[38] R. Usón, A. Laguna, M. Laguna, A. Usón, P. G. Jones, C.F. Erdbrugger, Organometallics 1987, 6, $1778-$ 1780.

[39] M. Contel, J. Garrido, M. C. Gimeno, M. Laguna, J. Chem. Soc., Dalton Trans. 1998, 1083 - 1084. 
[40] a) A. Burini, R. Galassi, B. R. Pietroni, J. P. Fackler, Jr., R. J. Staples, Chem. Commun. 1998, 95-96; b) A. Burini, R. Bravi, J. P. Fackler, Jr., R. Galassi, T. A. Grant, M. A. Omary, B. R. Pietroni, R. J. Staples, Inorg. Chem. 2000, 39, 3158-3165.

[41] E. J. Fernández, J. M. López-de-Luzuriaga, M. Monge, M.E. Olmos, R.C. Puelles, A. Laguna, A. A. Mohamed, J. P. Fackler, Jr., Inorg. Chem. 2008, 47, $8069-$ 8076.

[42] E. J. Fernández, A. Laguna, J. M. López-de-Luzuriaga, M. Monge, M. Montiel, M.E. Olmos, M. RodríguezCastillo, Organometallics 2006, 25, 3639-3646.
[43] E. J. Fernández, A. Laguna, J. M. López-de-Luzuriaga, M. Monge, M. Montiel, M.E. Olmos, J. Pérez, R.C. Puelles, J. C. Sáenz, J. Chem. Soc., Dalton Trans. 2005, $1162-1164$.

[44] R. Usón, A. Laguna, J. Vicente, J. Organomet. Chem. 1977, 131, $471-475$.

[45] R. Usón, A. Laguna, M. Laguna, B. R. Manzano, A. Tapia, Inorg. Chim. Acta 1985, 101, 151-153.

[46] G. M. Sheldrick, SHELXs/L-97, Programs for Crystal Structure Determination, University of Göttingen, Göttingen (Germany) 1997. See also: G. M. Sheldrick, Acta Crystallogr. 2008, A64, 112- 122. 